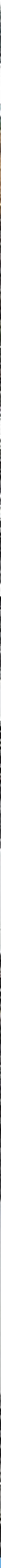

Toepassing klimaatstresstest open teelten

William Bijker \& Daan Verstand 


\section{Toepassing klimaatstresstest open teelten}

William Bijker

Daan Verstand

Wageningen University \& Research

Dit onderzoek is in opdracht van het ministerie van Landbouw, Natuur en Voedselkwaliteit uitgevoerd door Stichting Wageningen Research (WR), business unit Open Teelten in het kader van Klimaat Adaptatie Netwerk Open teelten (KANO) project, binnen het Kennis op Maat programma van de Topsector Agri \& Food en Tuinbouw \& Uitgangsmaterialen

Wageningen, December 2020

Rapport WPR-853 
Bijker, J.W., Verstand, D., 2020. Toepassing klimaatstresstest open teelten. Wageningen Research, Rapport WPR-853.

Dit rapport is gratis te downloaden op https://doi.org/10.18174/535133

Het rapport is tot stand gekomen in samenwerking met Agrifirm, LTO-Deltaplan Agrarisch Waterbeheer en het Verbond van Verzekeraars; partners in dit Kennis op Maat project.

Er zijn drie nieuwe voorbeeldbedrijven in de open teelten uitgewerkt doormiddel van het toepassen van de ontwikkelde klimaatstresstest methodiek. Naast de twee reeds bestaande uitwerkingen uit 2019 (Noordelijk pootgoedbedrijf en een Zuidoostelijk zand bedrijf), zijn nu de klimaatrisico's voor akkerbouwbedrijven in de Noordoostpolder, de Veenkoloniën en Zeeland uitgewerkt. Op deze manier zijn er voor deze vijf grote akkerbouwregio's een stresstest beschikbaar, die aanzet tot bewustwording en het nadenken over adaptatiemaatregelen. In alle drie de nieuwe uitwerkingen komt naar voren dat het bedrijfsrisico gaat toenemen en onder het $W_{H}$ klimaatscenario voor 2050 het meeste. Aardappel en ui blijken kwetsbare gewassen te zijn voor de toename van de geselecteerde klimaatfactoren, terwijl suikerbiet en granen weinig toenemende risico's van klimaatverandering zullen gaan ervaren. De nieuwe uitwerkingen hebben tevens geleid tot aanscherpingen in de methodiek en de gebruikte input data, zoals de frequenties van klimaatfactoren vanuit de KNMI klimaatscenario's. Het is ook duidelijk geworden dat een review van de geselecteerde klimaatfactoren en hun impacts nodig is, om zo nog herkenbaardere uitwerkingen te maken.

Trefwoorden: Klimaatverandering, open teelten, klimaatfactoren, risico's, stresstest.

(C) 2020 Wageningen, Stichting Wageningen Research, Wageningen Plant Research, Business unit Open Teelten, Postbus 430, 8200 AK, Lelystad, www.wur.nl/plant-research.

KvK: 09098104 te Arnhem

VAT NL no. 8113.83.696.B07

Stichting Wageningen Research. Alle rechten voorbehouden. Niets uit deze uitgave mag worden verveelvoudigd, opgeslagen in een geautomatiseerd gegevensbestand, of openbaar gemaakt, in enige vorm of op enige wijze, hetzij elektronisch, mechanisch, door fotokopieën, opnamen of enige andere manier zonder voorafgaande schriftelijke toestemming van Stichting Wageningen Research.

Stichting Wageningen Research is niet aansprakelijk voor eventuele schadelijke gevolgen die kunnen ontstaan bij gebruik van gegevens uit deze uitgave.

Rapport WPR-853

Foto omslag: Boerderij van de Toekomst, 2020 


\section{Inhoud}

1

Introductie en methodiek stresstest

1.1 Aanleiding en context

1.2 Introductie methodiek

1.2.1 Stappenplan

2

2.1 Akkerbouwbedrijf Noordoostpolder 10

2.2 Akkerbouwbedrijf Veenkoloniën

2.3 Akkerbouwbedrijf Zeeland

3

\section{Conclusie}

3.1 Resultaten

3.2 Aanbevelingen 



\section{$1 \quad$ Introductie en methodiek stresstest}

De aanleiding en context van dit rapport worden hieronder kort besproken, waarna vervolgens de methodiek wordt beschreven.

\subsection{Aanleiding en context}

In een voorgaand onderzoek is een klimaatstresstest ontwikkeld, die de klimaatrisico's voor bedrijven in de open teelten in kaart brengt. In dat onderzoek zijn tevens twee uitwerkingen volgens deze methodiek gemaakt, één voor een akkerbouwbedrijf in Noord Nederland en één van een bedrijf in Zuidoost Nederland. Ondanks de verschillen in weerstation en daarmee de voorspelde klimaatveranderingen en de verschillende bouwplannen, krijgen beide bedrijven te maken met aanzienlijke risico's (Verstand 2020; Verstand et al. 2020). Dat betekend dat adaptatie op een aantal punten noodzakelijk is. Het bleek dat deze uitwerkingen helpen om met boeren het gesprek over klimaatverandering aan te gaan en samen na te denken over de toekomstige risico's en mogelijke maatregelen om deze beheersbaar te houden. Maar met slechts twee voorbeelden was nog niet duidelijk hoe klimaatverandering akkerbouwbedrijven in andere regio's met andere bouwplannen gaan beïnvloeden.

Het in 2020 gestarte Kennis op Maat project KANO speelt hier op in door drie extra uitwerkingen van de stresstest te maken, met eigen bedrijfsopzetten en toegespitste klimaatvoorspellingen per weerstation. De drie voorbeelden zijn:

- Akkerbouwbedrijf in de Noordoostpolder

- Akkerbouwbedrijf in de Veenkoloniën

- Akkerbouwbedrijf in Zeeland

Deze drie uitwerkingen worden in dit rapport gepresenteerd.

Daarnaast is er ook update en verbeteringen in de methodiek en data gemaakt, zoals het aanscherpen van de frequenties van klimaatfactoren.

\subsection{Introductie methodiek}

Om klimaatadaptatie op lokaal niveau beter te kunnen vormgeven, is in aanvulling op de AgroClimateCalendar (ACC) (Schaap et al. 2011; Wit de, Swart, and Luijendijk 2009) een stresstest ontwikkeld op het bedrijfsniveau voor boerderijen in de open teelten (Verstand et al. 2020). Deze stresstest combineert de lokale klimaat- en gewas specifieke ACC data met gegevens over het bedrijf zoals arealen van gewassen in het bouwplan. Door dit te doen wordt voor de boer helder welke gewassen in het bouwplan het meeste risico lopen en hoe groot het aandeel daarvan is in het totale bedrijfsrisico voor klimaatverandering. Hieronder (1.2.1) wordt stap voor stap de methodiek voor de stresstest gepresenteerd.

De stresstest geeft voor een aantal gewassen de verandering van het risico's van klimaatfactoren ${ }^{1}$ weer, zonder adaptatiemaatregelen toe te passen. Dit ligt in lijn met de hierboven besproken ACC. De impact bij optreden van zo een klimaatfactor kan zowel kwantitatief (minder kg opbrengst) als kwalitatief (kwaliteitsproblemen producten) van aard zijn. Het jaarlijkse risico is de combinatie van de impact van een specifieke klimaatfactor en de jaarlijkse kans dat deze voorkomt (op basis van hoe vaak de klimaatfactor optreedt in een 30 jaar periode - het klimaat - , de frequentie genoemd). In de stresstest worden de risico's van alle klimaatfactoren samengenomen, waarbij sommige

\footnotetext{
${ }^{1}$ een kenmerkend weerfenomeen dat toegespitst is op een gewas en een impact heeft en zo schade veroorzaakt, bijv. een hittegolf tijdens het groeiseizoen van pootaardappelen, met doorwas als gevolg.
} 
klimaatfactoren vaker voorkomen dan andere en/of een grotere impact hebben. Een boer kan met deze informatie inschatten in hoeverre adaptatiemaatregelen nodig zijn op het bedrijf, gericht op specifieke klimaatfactoren (droogte, natte omstandigheden, hittegolven, etc.) of op bepaalde gewassen waar het risico het hoogst is.

De KWIN getallen van 2018 worden gebruikt voor het bepalen van de bruto geldopbrengst van de gewassen. De kosten van teelten zijn buiten beschouwing gelaten. De bruto geldopbrengst van een gewas verschilt per regio, zie van der Voort (2018). Deze verschillen zijn meegenomen in de stresstest analyse. De aanname is dat de KWIN opbrengsten gerealiseerd zijn onder de condities van het referentieklimaatscenario.

Per gewas zijn er een aantal klimaatfactoren geïdentificeerd en is beoordeeld hoe groot de bandbreedte impact van deze events is (vanuit de ACC). In de resultaten van de stresstest (2) worden deze gepresenteerd en nader uitgewerkt.

\subsubsection{Stappenplan}

Hieronder staat het stappenplan van de stresstest (Figuur 1). Dit stappenplan wordt stap voor stap gedetailleerd uitgewerkt en toegelicht.

1. Bedrijfsinformatie: gewassen, arealen en weerstation

2. Identificatie klimaatfactoren, frequenties en economische impact

3. Risico's per gewas per klimaatfactor

4. Betekenis bedrijf en prioritering adaptatienoodzaak

Figuur 1 Stappenplan van de stresstest-methodiek.

\section{Bedrijfsinformatie: gewassen en weerstation.}

De eerste stap is om de informatie te verzamelen van het landbouwbedrijf in kwestie:

- de gewassen aanwezig op het bedrijf, de arealen per gewas en de bruto geldopbrengst van deze gewassen uit de KWIN 2018 (van der Voort 2018), specifiek voor de regio in kwestie. De bruto geldopbrengst is de referentie, waarbij wordt uitgegaan dat hierin het huidige klimaat, en de impacts, frequenties en risico's in verwerkt is.

- de selectie van het regionale weerstation (meest nabije of representatieve van de vijf hierboven genoemd) om de frequentie van klimaatfactoren te bepalen, in het huidige en toekomstige klimaat voor klimaatscenario $G_{L} 2050$ en $W_{H} 2050$. In de stresstest hebben we de mogelijkheid om vijf weerstations te kiezen; Eelde, de Kooy, Maastricht, de Bilt en Vlissingen.

\section{Identificatie klimaatfactoren, frequenties en economische impacts}

Als de gewassen en het regionale weerstation zijn geselecteerd, kunnen de bijbehorende klimaatfactoren en frequenties uit de ACC worden bepaald. De frequentieverandering door klimaatverandering van de klimaatfactoren is van belang om tot de risico's (stap 3) te komen. De impacts van de klimaatfactoren bestaan uit een bandbreedte van economische impact bij optreden, met een lage en een hoge impact-inschatting (als bandbreedte), afhankelijk van de lokale teeltomstandigheden. Een goed perceel met een gunstig weer alvorens de klimaatfactor optreedt zal aan de lage kant zitten, terwijl enen kwetsbaar perceel juist een hogere impact kan verwachten. Per gewas worden de klimaatfactoren geanalyseerd.

\section{Risico's}

Zoals eerder genoemd is als referentie het huidige klimaat genomen en wordt er uitsluitend gekeken wat de risico verandering (toe- of afname frequenties klimaatfactoren) zijn die door klimaatverandering worden veroorzaakt voor de KNMI'14 scenario's (Klein Tank et al. 2015) voor de 30 jaar periode rond 2050; 2036-2065. 
Om te komen tot inzicht in wat klimaatverandering voor effect heeft op een boerenbedrijf, wordt gewerkt met risico's. Het risico is de kans vermenigvuldigt met het gevolg als een bepaalde event optreedt (impact).

$$
\text { Risico }=\text { kans } * \text { gevolg }
$$

De kans kan hier gezien worden als de frequentie-verandering in de periode rond 2050 ten opzichte van het heden uitgedrukt in de kans per jaar (frequentie delen door 30 jaar).

De kansen worden vermenigvuldigd met de impact (schade in $€$ ) per keer dat de klimaatfactor optreedt. Dat leidt tot het risico (kans*gevolg). Het risico is de berekende schade die klimaatfactor per jaar per hectare veroorzaakt. Dus als een klimaatfactor met 3 frequenties toeneemt in de toekomst ten opzichte van het heden, is de kans 0.1 (3/30) en de klimaatfactor bij optreden zorgt voor een impact van $€ 100$ (bijvoorbeeld $10 \%$ van een bruto geldopbrengst van $€ 1000$ ), is het risico van klimaatverandering per jaar per hectare dus $€ 10(0.1 * € 100)$.

Aangenomen is dat de kans, die hoort bij de frequentieverandering, op een klimaatfactor niet groter dan 1 kan zijn. Voor het risico betekent dit dat de schade maximaal 1 keer per jaar voor kan komen. Dit voorkomt overschatting van de schade. Immers, als de kans groter dan 1 is, wordt er gerekend met meer dan 1 keer per jaar de impact van de klimaatfactor optreedt. Er is echter een mogelijkheid in de realiteit dat een klimaatfactor wel 2 maal in een jaar voorkomt. Dat is in deze berekeningen niet meegenomen.

De risico's die uit de stresstest berekeningen komen zijn niet beïnvloed door extra adaptatiemaatregelen ten opzichte van de huidige teelt bewerkingen en gewas verzorging, oftewel de boer heeft niet extra ingegrepen naar aanleiding van het optreden van een klimaatfactor. Het is goed denkbaar dat als er bijvoorbeeld tijdens droogte beregend is, de daadwerkelijke impact van de klimaatfactor lager uit valt. Tevens zijn er geen extra kosten (voor bijvoorbeeld beregenen) of juist kostenbesparingen (door minder bewerkingen bijvoorbeeld) meegenomen bij het optreden van een klimaatfactor en het opstellen van het risico.

Om de risico's vergelijkbaar te maken, wordt gewerkt met een index. De huidige bruto geldopbrengst van een gewas (op basis van KWIN 2018) is geïndexeerd op 100. Als een klimaatfactor met veel impact in de toekomst vaker voorkomt, zal dat negatief doorwerken op de bruto geldopbrengst, waardoor de index lager dan 100 uitkomt. Komt die op 75 uit, betekent dit dat er nog 75\% van de huidige bruto geldopbrengst overblijft, onder dat scenario, als gevolg van het vaker optreden van die klimaatfactor. Andersom, als een klimaatfactor minder vaak voor gaat komen, kan de bruto geldopbrengst boven de 100 uitkomen in de toekomst, omdat er betere teeltomstandigheden zullen ontstaan. Het risico van een veranderend klimaat wordt zo direct gerelateerd aan de bruto geldopbrengst van gewassen. De index wordt berekend voor de lage en de hoge impact inschatting (de uitersten van de schade-bandbreedte uit de ACC).

Voorbeeldberekening risico, 1 gewas en 1 klimaatfactor.

In deze voorbeeld berekening wordt de berekeningswijze getoond voor 1 klimaatfactor in 1 gewas.

Uitgangsgegevens

- Pootaardappel

○ bruto geldopbrengst $€ 10080$, KWIN 2018 Pootaardappel Noord NL eigen mechanisatie (van der Voort 2018).

- Klimaatfactor: hittegolf

- Type impact: doorwas.

- Periode van kwetsbaarheid: juli-september

- Weerstation: Eelde

\begin{tabular}{|l|l|l|}
\hline Frequentie heden & $\begin{array}{l}\text { Frequentie } \\
\text { verandering GL 2050 }\end{array}$ & $\begin{array}{l}\text { Frequentie verandering } \\
\text { WH } 2050\end{array}$ \\
\hline $\mathbf{1 1}$ & +7 & +26 \\
\hline
\end{tabular}


De frequenties van hittegolven gaan sterk toenemen in de toekomst. In de 30 jaar periode rond 2050 (dus 2036 en 2065) gaan er dus 7 of 26 extra hittegolven plaatsvinden, in $G_{L} 2050$ en $W_{H} 2050$ respectievelijk. De kansen voor in de risico berekening zijn dan $7 / 30=0.23$ in $G_{L} 2050$ en $26 / 30=0.867$ in $W_{H} 2050$.

De impact van een hittegolf is in de lage inschatting $25 \%$ van de bruto geldopbrengst en zelfs $75 \%$ in de hoge impact inschatting.

\begin{tabular}{|l|l|l|}
\hline & Lage impact inschatting & Hoge impact inschatting \\
\hline Impact per event & $25 \%->€ 2520$ & $75 \%->€ 7560$ \\
\hline
\end{tabular}

\section{Risico berekening}

Door de kans te vermenigvuldigen met de impact per event, krijgen we de het risico per hectare per jaar. In dit geval is dat:

- Heden: Bruto geldopbrengst $=€ 10080$, waarin de huidige risico al ingebed is.

- 2050 G 2050: risico toename door een frequentie toename (+7, kans is 0.23 ) tussen $€ 580$ en $€ 1739$

○ Lage impact: $0.23 * 2520=€ 580$

- Hoge impact: $0.23 * 7560=€ 1739$

- $2050 \mathrm{~W}_{\mathrm{H}}$ 2050: risico toename door een frequentie toename (+26, kans is 0.867 ) tussen $€ 2185$ en $€ 6555$

$$
\begin{array}{ll}
\circ & 0.867 * 2520=€ 2185 \\
\circ & 0.867 * 7560=€ 6555
\end{array}
$$

De hedendaagse index staat op 100,waar de huidige bruto geldopbrengst $€ 10080$ is. De toename van het risico, zal leiden tot een lagere index:

- Huidige index is 100

- Index in $G_{L} 2050$ :

○ Lage impact: $100-((580 / 10080) * 100)=94$

○ Hoge impact: $100-((1739 / 10080) * 100)=83$

- Index $W_{H} 2050$

$$
\begin{aligned}
& \circ \text { Lage impact: } 100-((2185 / 10080) * 100)=78 \\
& \circ \quad \text { Hoge impact: } 100-((6555 / 10080) * 100)=35
\end{aligned}
$$

Het $W_{H} 2050$ scenario heeft hier het de grootse negatieve effect. Bij de hoge impact inschatting blijft er in dit scenario, jaarlijks slechts $35 \%$ van de bruto geldopbrengst van pootaardappel over als gevolg van de toename van de frequentie van hittegolven.

\section{Betekenis en prioritering}

Tot slot wordt bepaald wat de grootste uitdagingen van klimaatverandering zullen gaan worden voor het bedrijf, door een prioritering van gewassen en specifieke klimaatfactoren. Deze prioritering kan de basis zijn voor een gerichte adaptatiestrategie op het bedrijf.

Hiervoor wordt de toename in het risico door klimaatverandering per hectare per jaar van alle klimaatfactoren van de gewassen bij elkaar opgeteld, wordt het afgewogen aan de hand van de arealen van de gewassen (hoe groter het areaal in het bouwplan, hoe groter de weging van het desbetreffende risico op bouwplanniveau) en afgezet tegen de bruto geldopbrengst van het bedrijf, per hectare. Deze bruto geldopbrengst per hectare is een gewogen gemiddelde van de bruto geldopbrengsten van de aanwezige gewassen, berekend per hectare. Let op: het risico van een gewas kan in sommige gevallen, doordat risico's opgeteld worden, groter uitvallen dan de bijdrage van het gewas aan de bouwplan bruto geldopbrengst per hectare. In deze gevallen is het risico van dat gewas gelijk gezet aan de bijdrage van het gewas aan de bouwplan bruto geldopbrengst (maximale risico = $100 \%$ van de bijdrage aan bruto geldopbrengst). Doen we dit niet, dan zou dit gewas ook de opbrengsten van de andere gewassen beïnvloeden, wat niet kan gebeuren. De risico-bijdrage van een gewas wordt ook getoond, en zo kan er een beeld gevormd worden over welk gewas nu veel of weinig bijdraagt aan het bouwplanrisico en hoe zich dat verhoudt ten opzichte van de bouwplan bruto geldopbrengst per hectare. 
Een belangrijke notie hier is dat de risico's niet zijn gecorrigeerd voor het feit dat er verschillende klimaatfactoren in één jaar plaatsvinden, waardoor de schade lager uit zal vallen in vergelijking met de situatie dat de klimaatfactoren in verschillende jaren optreedt. Er kan dus sprake zijn van een overschatting van het totale bedrijfsrisico. 


\section{Stresstest casussen}

Hieronder worden voor drie akkerbouwbedrijven de stresstestresultaten gepresenteerd.

\subsection{Akkerbouwbedrijf Noordoostpolder}

De stappen van de stresstest worden hieronder gevolgd en per stap worden de resultaten van een akkerbouwbedrijf in de Noordoostpolder gepresenteerd.

\section{Stap 1 Het bedrijf}

- $\quad$ Gewassen in bedrijf (totaal 100ha):

- Pootaardappelen 33,3\% van areaal

- Bruto geldopbrengst $€ 11.172$, Pootaardappelen, kleigrond, IJsselmeerpolders (van der Voort 2018)

- Wintertarwe $16,7 \%$ van areaal

- Bruto geldopbrengst $€ 2.143$, Wintertarwe, kleigrond, Zuidwest Nederland, IJsselmeerpolders (van der Voort 2018)

- Suikerbieten $16,7 \%$ van areaal

- Bruto geldopbrengst $€ 4.322$, Suikerbieten, kleigrond, IJsselmeerpolders (van der Voort 2018)

- Zaaiuien $16,7 \%$ van areaal

- Bruto geldopbrengst $€ 5.950$, Zaaiuien, kleigrond, IJsselmeerpolders (van der Voort 2018)

- Peen $16,7 \%$ van areaal

- Bruto geldopbrengst $€ 10.200$, Grove peen (b-peen) (bewaar) (M. Van der Voort, persoonlijke communicatie, 30 juni 2020)

- Weerstation: De Bilt

\section{Stap 2 De klimaatfactoren}

De klimaatfactoren, hun meteorologische definitie, periode, type impact en economische impact van het bouwplan zijn hieronder in tabelvorm getoond (Tabel 1), met hun klimatologische definitie, periode van kwetsbaarheid voor het gewas, de type impact bij optreden, de economische impact (als percentage van de bruto geldopbrengst (kg*prijs) en de frequenties per 30 jaar voor de huidige situatie (1981-2010) en de frequentie verandering in de twee toekomstscenario $\mathrm{G}_{\llcorner}$en $W_{\mathrm{H}}$ (20362065). 


\begin{tabular}{|c|c|c|c|c|c|c|c|c|c|}
\hline Gewas & Klimaatfactor & Meteorologische definitie & $\begin{array}{l}\text { Periode van } \\
\text { kwetsbaarheid }\end{array}$ & Type impact & $\begin{array}{l}\text { Impact } \\
\text { laag }\end{array}$ & $\begin{array}{l}\text { Impact } \\
\text { hoog }\end{array}$ & $\begin{array}{l}\text { Frequentie } \\
\text { heden }\end{array}$ & $\begin{array}{l}\Delta G_{L} \\
2050^{1}\end{array}$ & $\begin{array}{l}\Delta W_{H} \\
2050^{1}\end{array}$ \\
\hline \multirow[t]{6}{*}{ Pootaardappelen } & Natte periode & Ten minste $75 \%$ van 21 dagen met een dagelijkse neerslag $\geq 0,5 \mathrm{~mm}$ & Okt-Apr & Verlate pootdatum & $0 \%$ & $0 \%$ & 41 & 2 & 15 \\
\hline & $\begin{array}{l}\text { Hevige } \\
\text { neerslag }\end{array}$ & Dagelijkse neerslag $\geq 45 \mathrm{~mm}$ of in 3 dagen $\geq 60 \mathrm{~mm}$ & Mei-Sep & Rotten van knollen & $25 \%$ & $75 \%$ & 8 & 3 & 6 \\
\hline & Hittegolf & Minimaal 3 dagen $\geq 30^{\circ} \mathrm{C}$ in een periode van minimaal 5 dagen $\geq 25^{\circ} \mathrm{C}$ & Jul-Sep & Doorwas en opbrengstderving & $25 \%$ & $75 \%$ & 12 & 11 & 29 \\
\hline & Warm en nat & $\begin{array}{l}\text { Minimaal } 14 \text { dagen met een maximumtemperatuur } \geq 20^{\circ} \mathrm{C} \text { en gedurende } 50 \% \text { van } \\
\text { de dagen een neerslag } \geq 0,5 \mathrm{~mm}\end{array}$ & Jul-Sep & $\begin{array}{l}\text { Pectobacterium en Dickeya } \\
\text { veroorzakers van natrot en } \\
\text { zwartbenigheid }\end{array}$ & $10 \%$ & $50 \%$ & 5 & 11 & 18 \\
\hline & Natte periode & Ten minste $75 \%$ van 21 dagen met een dagelijkse neerslag $\geq 0,5 \mathrm{~mm}$ & Jun-Sep & $\begin{array}{l}\text { Niet mogelijk om te spuiten } \\
\text { tegen Fytoftora infestans }\end{array}$ & $50 \%$ & $100 \%$ & 18 & -3 & -6 \\
\hline & Natte periode & Ten minste $75 \%$ van 21 dagen met een dagelijkse neerslag $\geq 0,5 \mathrm{~mm}$ & Aug-okt & Schade aan de knollen & $0 \%$ & $0 \%$ & 13 & 0 & -1 \\
\hline \multirow[t]{7}{*}{ Wintertarwe } & Natte periode & Ten minste $75 \%$ van 21 dagen met een dagelijkse neerslag $\geq 0,5 \mathrm{~mm}$ & Okt-Dec & Uitgestelde zaaidatum & $0 \%$ & $0 \%$ & 20 & 1 & 8 \\
\hline & $\begin{array}{l}\text { Vriezen en } \\
\text { dooien }\end{array}$ & $\begin{array}{l}\text { Periode van minimaal } 3 \text { dagen herhaalde vorst en ontdooien (minimum } \leq-1^{\circ} \mathrm{C} \text { en } \\
\text { maximum } \geq 1^{\circ} \mathrm{C} \text { ) na periode van sterke vorst (minimum } \leq-10^{\circ} \mathrm{C} \text { ), incl. een } \\
\text { overgangsperiode van } 2 \text { dagen naar ontdooien. }\end{array}$ & Nov-Mrt & Wortelschade & $10 \%$ & $50 \%$ & 3 & -2 & -2 \\
\hline & Droge periode & Minimaal 40 dagen met een neerslagsom $\leq 10 \mathrm{~mm}$ & Jun-Aug & Lagere graanopbrengst & $10 \%$ & $50 \%$ & 3 & 0 & 3 \\
\hline & Natte periode & Ten minste $75 \%$ van 21 dagen met een dagelijkse neerslag $\geq 0,5 \mathrm{~mm}$ & Apr-Mei & Roest en Septoria & $25 \%$ & $75 \%$ & 6 & 2 & -1 \\
\hline & Natte periode & Ten minste $75 \%$ van 21 dagen met een dagelijkse neerslag $\geq 0,5 \mathrm{~mm}$ & Mei-Jul & $\begin{array}{l}\text { Roest, Fusarium en Septoria en } \\
\text { een lagere kwaliteit }\end{array}$ & $25 \%$ & $75 \%$ & 13 & -1 & -5 \\
\hline & $\begin{array}{l}\text { Hevige } \\
\text { neerslag }\end{array}$ & Dagelijkse neerslag $\geq 45 \mathrm{~mm}$ & Mei-Aug & Niet mogelijk om te oogsten & $0 \%$ & $0 \%$ & 2 & 1 & 3 \\
\hline & Natte periode & Ten minste $75 \%$ van 21 dagen met een dagelijkse neerslag $\geq 0,5 \mathrm{~mm}$ & Jul-Sep & Niet mogelijk om te oogsten & $10 \%$ & $75 \%$ & 13 & -1 & -3 \\
\hline \multirow[t]{5}{*}{ Suikerbieten } & Droge periode & Minimaal 30 dagen met een neerslagsom $\leq 5 \mathrm{~mm}$ & Mrt-Apr & Opkomstproblemen & $25 \%$ & $35 \%$ & 3 & 0 & -1 \\
\hline & Natte periode & Minimaal $10 \%$ van 28 dagen met een neerslagpercentage $\geq 10 \mathrm{~mm}$ & Aug-Sep & Lagere suiker inhoud & $10 \%$ & $25 \%$ & 27 & 1 & 0 \\
\hline & Natte periode & Minimaal $75 \%$ van 14 dagen met een dagelijkse neerslag $\geq 0,5 \mathrm{~mm}$ & Apr-Jul & $\begin{array}{l}\text { Natte condities veroorzaken } \\
\text { Rhizomania }\end{array}$ & $10 \%$ & $50 \%$ & 29 & -4 & -11 \\
\hline & Warme winter & Minimaal 14 dagen met een maximumtemperatuur $\geq 10^{\circ} \mathrm{C}$ & Dec-Mrt & $\begin{array}{l}\text { In opslag verliezen bieten suiker } \\
\text { inhoud }\end{array}$ & $10 \%$ & $25 \%$ & 4 & 7 & 27 \\
\hline & Nachtvorst & Minimaal 1 dag met een minimumtemperatuur $\leq-3^{\circ} \mathrm{C}$ & Mrt-Apr & Bevriezen zaailingen & $10 \%$ & $20 \%$ & 47 & -30 & -30 \\
\hline \multirow[t]{5}{*}{ Zaaiuien } & Droge periode & Minimaal 30 dagen met een neerslagsom $\leq 5 \mathrm{~mm}$ & Feb-Apr & Droogteschade zaailingen & $0 \%$ & $100 \%$ & 5 & 0 & -1 \\
\hline & Droge periode & Minimaal 30 dagen met een neerslagsom $\leq 10 \mathrm{~mm}$ & Jun-Jul & Droogteschade & $30 \%$ & $40 \%$ & 5 & 0 & 6 \\
\hline & $\begin{array}{l}\text { Hevige } \\
\text { neerslag }\end{array}$ & Dagelijkse neerslag van $\geq 45 \mathrm{~mm}$ of in 8 dagen $\geq 100 \mathrm{~mm}$ & Sep-Okt & $\begin{array}{l}\text { Bacteriën infecteren bladeren } \\
\text { (via bodemdeeltjes) }\end{array}$ & $0 \%$ & $100 \%$ & 4 & 1 & 0 \\
\hline & $\begin{array}{l}\text { Hevige } \\
\text { neerslag }\end{array}$ & Dagelijkse neerslag $\geq 45 \mathrm{~mm}$ & Jul-Aug & Schimmels infecteren bladeren & $10 \%$ & $50 \%$ & 1 & 1 & 3 \\
\hline & Warm en nat & $\begin{array}{l}\text { Minimaal } 14 \text { dagen met een maximumtemperatuur } \geq 20^{\circ} \mathrm{C} \text { en gedurende } 50 \% \text { van } \\
\text { de dagen een neerslag } \geq 0,5 \mathrm{~mm}\end{array}$ & Jun-Aug & Schimmelinfecties & $50 \%$ & $60 \%$ & 5 & 11 & 22 \\
\hline \multirow[t]{4}{*}{ Peen } & $\begin{array}{l}\text { Hevige } \\
\text { neerslag }\end{array}$ & Dagelijkse neerslag $\geq 45 \mathrm{~mm}$ of in 3 dagen $\geq 60 \mathrm{~mm}$ & Jun-Nov & $\begin{array}{l}\text { Met water verzadigde bodem } \\
\text { veroorzaakt rot }\end{array}$ & $10 \%$ & $100 \%$ & 12 & 4 & 7 \\
\hline & $\begin{array}{l}\text { Hevige } \\
\text { neerslag }\end{array}$ & Dagelijkse neerslag $\geq 45 \mathrm{~mm}$ & Aug-Nov & Rotten van wortels & $10 \%$ & $50 \%$ & 1 & 0 & 1 \\
\hline & Nachtvorst & Minimaal 1 dag met een minimumtemperatuur $\leq-2^{\circ} \mathrm{C}$ & Mei-Jun & Scheuren van wortel & $0 \%$ & $30 \%$ & 2 & -2 & -2 \\
\hline & Warme periode & Minimaal 14 dagen met een maximumtemperatuur $\geq 30^{\circ} \mathrm{C}$ & Jul-Aug & Gereduceerde groei & $0 \%$ & $15 \%$ & 0 & 0 & 1 \\
\hline
\end{tabular}

Tabel 1

Klimaatfactoren meteorologische definitie, periode, type impact en

economische impact (\%) voor een akkerbouwbedrijf in de

Noordoostpolder op basis van weerstation De Bilt.

${ }^{1}$ Verwachte verandering $(\Delta)$ van de frequenties onder de KNMI-klimaatscenario's (GL 2050 en $W_{H}$ 2050) t.o.v. de referentieperiode 1981-2010 
Uit Tabel 1 blijkt dat naar verwachting voor de meeste klimaatfactoren en klimaatscenario's een verandering gaat optreden van de frequenties. Voor pootaardappelen valt op dat de klimaatfactoren hittegolf $\left(\Delta G_{L}-W_{H}=\right.$ $[11 ; 29])$ en warm en nat $\left(\Delta G_{L}-W_{H}=[11 ; 18]\right)$ onder beide scenario's sterk toenemen. De frequenties van de klimaatfactor natte periode $\left(\Delta \mathrm{G}_{L}-\mathrm{W}_{\mathrm{H}}=[-3 ;-6]\right)$ in de zomer nemen naar verwachting in beide scenario's juist af. Bij wintertarwe zijn de toenames geringer, zo neemt natte periode in de winter $\left(\Delta G_{L}-W_{H}=[1 ; 8]\right)$ en hevige neerslag $\left(\Delta G_{L}-W_{H}=[1 ; 3]\right)$ met een paar frequenties toe. Daarnaast nemen de klimaatfactoren natte periode (mei - juni) $\left(\Delta \mathrm{G}_{L}-\mathrm{W}_{H}=[-1 ;-5]\right)$ en vriezen en dooien $\left(\Delta \mathrm{G}_{\mathrm{L}}-\mathrm{W}_{\mathrm{H}}=[-2 ;-2]\right)$ af. Voor suikerbieten zijn de verschillen tussen stijgingen en dalingen in frequenties groter, zo nemen frequenties van warme winter $\left(\Delta G_{L}-W_{H}=[7 ; 27]\right)$ toe en nemen de frequenties van nachtvorst $\left(\Delta G_{L}-W_{H}=[-30 ;-30]\right)$ sterk af. Van de klimaatfactoren van zaaiuien laat met name warm en nat $\left(\Delta G_{L}-W_{H}=[11 ; 22]\right)$ in de zomer een forse stijging zien, de overige klimaatfactoren nemen niet of matig toe. Voor peen speelt met name de klimaatfactor hevige neerslag $\left(\Delta \mathrm{G}_{\mathrm{L}}-\mathrm{W}_{\mathrm{H}}=[4 ; 7]\right)$ een rol, naast dat deze het vaakst voor komt in de referentieperiode, neemt deze onder de $\mathrm{G}_{\mathrm{L}}$ - en $\mathrm{W}_{\mathrm{H}}$-scenario's het sterkst toe.

\section{Stap 3 Risico's}

De risico's als gevolg van een veranderende frequentie door klimaatverandering van de klimaatfactoren, zijn inzichtelijk gemaakt in Tabel 2. De hedendaagse bruto geldopbrengst van een gewas is als uitgangspunt genomen en geïndexeerd op 100. Per klimaatfactor is het effect van een toe of afnemend risico te zien, uitgedrukt in effect op de index van de bruto geldopbrengst. Dat is gedaan voor de twee scenario's in $2050\left(G_{L}\right.$ en $W_{H}$ ) en voor de lage en hoge impact inschatting van een klimaatfactor. Deze impacts per event blijven in de toekomst gelijk, maar de frequenties kunnen veranderen, waardoor dus ook het risico verandert.

Tabel 2 Geïndexeerde effecten van risico's voor klimaatscenario's en impact (laag en hoog) ten opzichte van referentieperiode per klimaatfactor voor een akkerbouwbedrijf in de Noordoostpolder.

\begin{tabular}{|c|c|c|c|c|c|c|}
\hline Gewas & Klimaatfactor & Ref. periode & GL 2050 laag & GL 2050 hoog & Wн 2050 laag & Wн 2050 hoog \\
\hline \multirow[t]{4}{*}{ Pootaardappelen } & Natte periode & 100 & 100 & 100 & 100 & 100 \\
\hline & Hevige neerslag & 100 & 98 & 93 & 95 & 85 \\
\hline & Warm en nat & 100 & 96 & 82 & 94 & 70 \\
\hline & Natte periode & 100 & 105 & 110 & 110 & 120 \\
\hline \multirow[t]{5}{*}{ Wintertarwe } & Natte periode & 100 & 100 & 100 & 100 & 100 \\
\hline & Vriezen en dooien & 100 & 101 & 103 & 101 & 103 \\
\hline & Droge periode & 100 & 100 & 100 & 99 & 95 \\
\hline & Natte periode & 100 & 98 & 95 & 101 & 103 \\
\hline & Natte periode & 100 & 101 & 103 & 104 & 113 \\
\hline \multirow{4}{*}{ Suikerbieten } & Natte periode & 100 & 100 & 99 & 100 & 100 \\
\hline & Natte periode & 100 & 101 & 107 & 104 & 118 \\
\hline & Warme winter & 100 & 98 & 94 & 91 & 78 \\
\hline & Nachtvorst & 100 & 110 & 120 & 110 & 120 \\
\hline \multirow[t]{5}{*}{ Zaaiuien } & Droge periode & 100 & 100 & 100 & 100 & 103 \\
\hline & Droge periode & 100 & 100 & 100 & 94 & 92 \\
\hline & Hevige neerslag & 100 & 100 & 97 & 100 & 100 \\
\hline & Hevige neerslag & 100 & 100 & 98 & 99 & 95 \\
\hline & Warm en nat & 100 & 82 & 78 & 63 & 56 \\
\hline
\end{tabular}


Een daling of stijging van de indexen van de individuele klimaatfactoren in Tabel 2 valt samen met een daling of stijging van de hiervoor beschreven frequenties en de hoogte van de impact uit Tabel 1. Voor pootaardappelen valt op dat de indexen van de klimaatfactoren hittegolf $(\Delta \mathrm{GL}$ laag - hoog $=[91 ; 73]$, $W_{H}$ laag - hoog $\left.=[91 ; 73]\right)$ en warm en nat $\left(\Delta \mathrm{GL}\right.$ laag - hoog $=[96 ; 82], W_{H}$ laag - hoog $\left.=[94 ; 70]\right)$ onder beide scenario's sterk dalen. Het risico voor de klimaatfactor natte periode ( $\Delta \mathrm{GL}$ laag - hoog= $[105 ; 110], W_{H}$ laag - hoog $\left.=[110 ; 120]\right)$ in de zomer neemt naar verwachting in beide scenario's af. Bij wintertarwe zijn de veranderingen van de indexen geringer, zo neemt de index van natte periode in april en mei in het GL-scenario af ( $\Delta$ G laag - hoog= $[98 ; 95])$, maar stijgt deze in de in het $\mathrm{WH}_{\mathrm{H}^{-}}$ scenario $(\Delta$ GL laag - hoog $=[101 ; 103])$. De indexen van natte periode (mei-juni) $(\Delta \mathrm{GL}$ laag - hoog= $[101 ; 103], W_{H}$ laag - hoog $\left.=[104 ; 113]\right)$ stijgen in beide klimaatscenario's. Voor suikerbieten zijn de verschillen tussen de stijgingen en dalingen van de indexen groter. Naar verwachting nemen de indexen van de klimaatfactor warme winter af $\left(\Delta \mathrm{GL}\right.$ laag - hoog $=[98 ; 94], \mathrm{W}_{\mathrm{H}}$ laag - hoog $\left.=[91 ; 78]\right)$ en nemen de indexen van nachtvorst toe $\left(\Delta \mathrm{GL}\right.$ laag - hoog $=[110 ; 120], W_{H}$ laag - hoog $=[110 ;$ $120]$ ). Van de indexen van zaaiuien laat met name de klimaatfactor warm en nat ( $\Delta G_{L}$ laag - hoog= $[82 ; 78], W_{H}$ laag - hoog $=[63 ; 56]$ ) een daling zien, de overige indexen veranderen niet of matig. Voor peen daalt met name de index van hevige neerslag $\left(\Delta G_{L}\right.$ laag - hoog $=[99 ; 87], W_{H}$ laag hoog $=[98 ; 77])$, de indexen van de overige klimaatfactoren veranderen niet of matig.

\section{Stap 4 Betekenis bedrijf}

Om de individuele risico's van klimaatfactoren per gewas op te schalen naar bedrijfsniveau, wordt gekeken naar de bouwplan bruto geldopbrengst. De bouwplan bruto geldopbrengst is een gewogen gemiddelde van de bruto geldopbrengst van de gewassen, naar hun aandeel in het bouwplan. In dit voorbeeldbedrijf van 100 hectare, is $33,3 \%$ pootaardappel, $16,7 \%$ wintertarwe, $16,7 \%$ suikerbiet, $16,7 \%$ zaai-ui en $16,7 \%$ peen. Hoe groter het aandeel van een gewas, hoe groter de bijdrage daarvan aan de bouwplan bruto geldopbrengst. De bouwplan bruto geldopbrengst is hier berekend op $€ 7493$ per hectare per jaar.

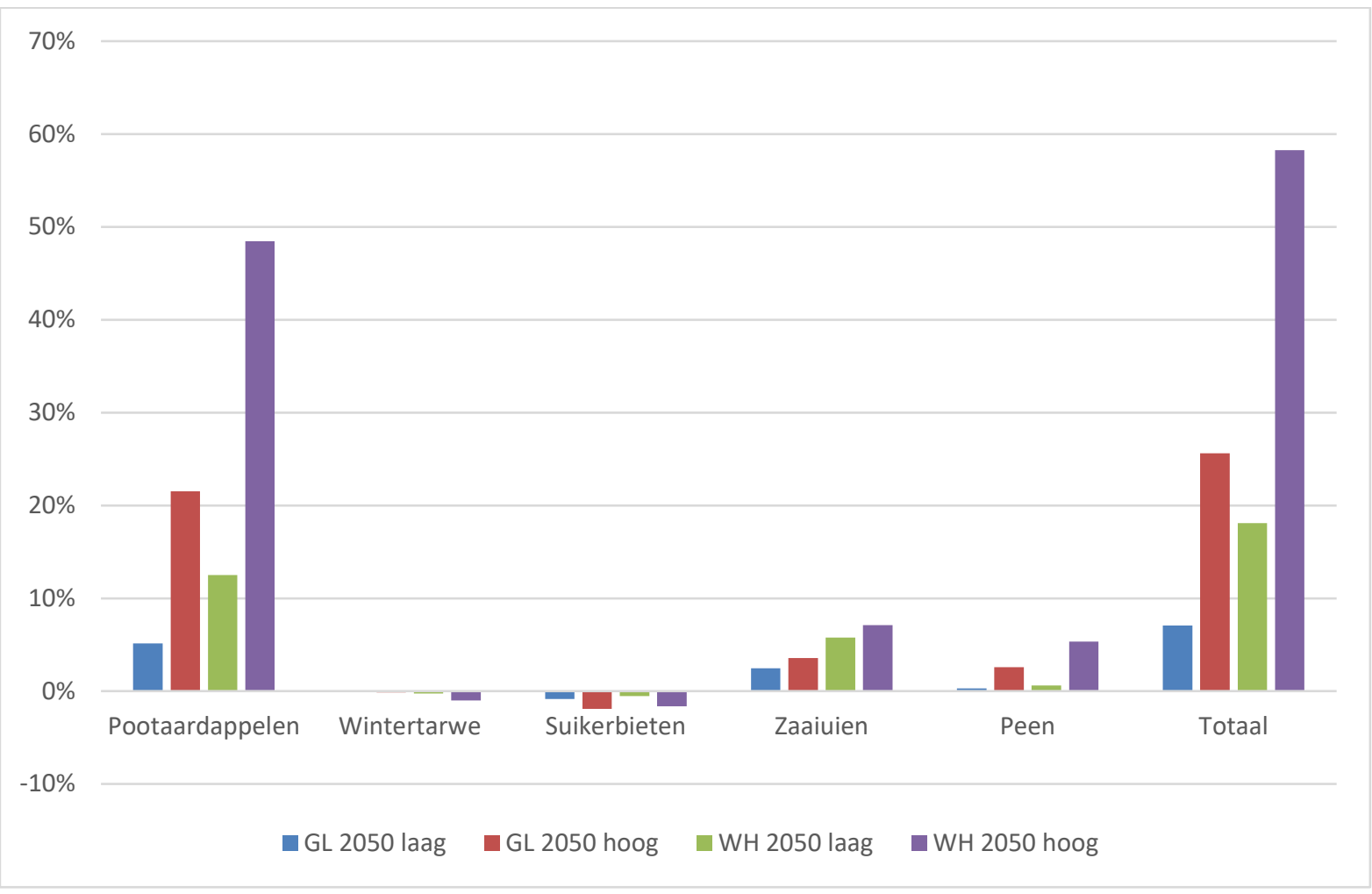

Figuur 2 Risico van klimaatverandering per gewas als percentage van de bouwplan bruto geldopbrengst in de Noordoostpolder.

Figuur 2 toont per gewas het risico als percentage van de bouwplan bruto geldopbrengst per hectare. Dit is een gewogen gemiddelde, dus hoe groter het aandeel van het gewas, hoe groter de bijdrage aan het bouwplan risico van dat gewas zal zijn. De laatste kolom toont het totale bedrijfsrisico. 
In Figuur 2 is te zien dat het totale bedrijfsrisico door klimaatverandering in dit bouwplan toeneemt ( $\Delta$ $\mathrm{G}$ laag - hoog $=[7 \% ; 26 \%], W_{H}$ laag - hoog $\left.=[18 \% ; 58 \%]\right)$. Wat verder opvalt is dat pootaardappelen, in elk scenario, het grootste risico met zich meebrengen in de toekomst ( $\Delta \mathrm{G}_{\mathrm{L}}$ laag hoog $=[2 \% ; 22 \%], W_{H}$ laag - hoog $\left.=[13 \% ; 48 \%]\right)$. Dit is te verklaren doordat pootaardappelen gevoelig zijn voor weersextremen (met name door de toename van hittegolven met doorwas) en daarbij een belangrijk aandeel (33,3\%) hebben in het bouwplan met een hoge bruto geldopbrengst. Ook voor de gewassen zaaiuien ( $\Delta \mathrm{GL}$ laag - hoog $=[2 \% ; 22 \%], \mathrm{W}_{\mathrm{H}}$ laag - hoog $=[13 \% ; 48 \%]$ ) en peen neemt het risico van weersextremen door klimaatverandering toe. Voor gewassen als wintertarwe en suikerbieten neemt in de toekomst, voornamelijk door warmere winters, het risico juist iets af.

De toename van het risico is sterk afhankelijk van het klimaatscenario en de impact (laag of hoog). Naast de vastgestelde klimaatfactoren, kunnen telers door warmere winters vaker te maken krijgen met aardappelopslag, dit kan leiden tot de aantrekking van aaltjes en een bron vormen van Fytoftora. De laatstgenoemde kan met effectieve bespuitingen tegengegaan worden. Ook de coloradokever zal naar verwachting vaker voorkomen door de stijging van de temperaturen in de winters en hierdoor meer problemen geven in het groeiseizoen. Daarnaast kunnen bladluizen tijdens het groeiseizoen door hogere temperaturen een groter risico vormen in virusoverdracht wat vervolgens tot hogere afkeuring kan leiden. Het is van belang dat telers hiertegen effectieve middelen blijven inzetten en ontwikkelen.

De klimaatscenario's $G_{L}$ en $W_{H}$ laten beide een toename van het aantal weersextremen zien. Hoewel er verschil zit in de mate waarin individuele klimaatfactoren een risico gaan vormen in de toekomst, laten beide scenario's een overwegende toename van natte, warme en droge weersextremen zien, de klimaatfactoren welke door lage temperaturen worden bepaald laten een afname. Bij

adaptatiemaatregelen is het dus belangrijk om te kijken naar maatregelen die voor meerdere situaties effectief kunnen zijn (zoals goede bodemstructuur en peil gestuurde drainage). Veel van deze maatregelen zullen soms al zijn uitgevoerd op het boerenbedrijf. Daarom kan het ook van belang zijn om te kijken naar rassenkeus.

\subsection{Akkerbouwbedrijf Veenkoloniën}

Hieronder worden, per stap van de methodiek, de resultaten van een akkerbouwbedrijf in de Veenkoloniën gepresenteerd.

\section{Stap 1 Het bedrijf}

- Gewassen in bedrijf (totaal 100 ha):

- Zetmeelaardappelen $50 \%$ van areaal

- Bruto geldopbrengst $€ 3234$, Zetmeelaardappelen (van der Voort 2018)

- Zomergerst $20 \%$ van areaal

- Bruto geldopbrengst $€ 1.444$, Zomergerst, noordelijke zand- en dalgrond (van der Voort 2018)

- Suikerbieten $25 \%$ van areaal

- Bruto geldopbrengst $€ 3435$, Suikerbieten, noordelijk zand- en dalgrond (van der Voort 2018)

- Zaaiuien $5 \%$ van areaal

- Bruto geldopbrengst $€ 4797.5$ Zaaiuien, Noordelijke zand- en dalgrond? (M. Van der Voort, persoonlijke communicatie, 30 juni 2020)

- Weerstation: Eelde

\section{Stap 2 De klimaatfactoren}

De klimaatfactoren, hun meteorologische definitie, periode, type impact en economische impact van het bouwplan zijn hieronder in tabelvorm getoond (Tabel 3), met hun klimatologische definitie, periode van kwetsbaarheid voor het gewas, de type impact bij optreden, de economische impact (als percentage van de bruto geldopbrengst (kg*prijs) en de frequenties per 30 jaar voor de huidige situatie (1981-2010) en de frequentie verandering in de twee toekomstscenario GL en WH (20362065). 
Tabel 3 Klimaatfactoren, meteorologische definitie, periode, type impact en economische impact (\%) voor een akkerbouwbedrijf in de Veenkoloniën op basis van weerstation Eelde.

\begin{tabular}{|c|c|c|c|c|c|c|c|c|c|}
\hline Gewas & Klimaatfactor & Meteorologische definitie & $\begin{array}{l}\text { Periode van } \\
\text { kwetsbaarheid }\end{array}$ & Type impact & $\begin{array}{l}\text { Impact } \\
\text { laag }\end{array}$ & $\begin{array}{l}\text { Impact } \\
\text { hoog }\end{array}$ & $\begin{array}{l}\text { Frequentie } \\
\text { heden }\end{array}$ & $\begin{array}{l}\Delta G_{L} \\
2050^{1}\end{array}$ & $\begin{array}{l}\Delta W_{H} \\
2050^{1}\end{array}$ \\
\hline \multirow[t]{6}{*}{ Zetmeelaardappelen } & Natte periode & $\begin{array}{l}\text { Ten minste } 75 \% \text { van } 21 \text { dagen met een dagelijkse neerslag } \geq \\
0,5 \mathrm{~mm}\end{array}$ & Mrt-Apr & Verlate pootdatum & $0 \%$ & $0 \%$ & 45 & 1 & 10 \\
\hline & Hevige neerslag & Dagelijkse neerslag $\geq 45 \mathrm{~mm}$ of in 3 dagen $\geq 60 \mathrm{~mm}$ & Mei-Sep & Rotten van knollen & $25 \%$ & $75 \%$ & 5 & 1 & 2 \\
\hline & Hittegolf & $\begin{array}{l}\text { Minimaal } 3 \text { dagen } \geq 30^{\circ} \mathrm{C} \text { in een periode van minimaal } 5 \text { dagen } \\
\geq 25^{\circ} \mathrm{C}\end{array}$ & Jul-Sep & Doorwas en opbrengstderving & $25 \%$ & $75 \%$ & 11 & 8 & 22 \\
\hline & Warm en nat & $\begin{array}{l}\text { Minimaal } 14 \text { dagen met een maximumtemperatuur } \geq 20^{\circ} \mathrm{C} \text { en } \\
\text { gedurende } 50 \% \text { van de dagen een neerslag } \geq 0,5 \mathrm{~mm}\end{array}$ & Jul-Sep & $\begin{array}{l}\text { Pectobacterium en Dickeya veroorzakers } \\
\text { van natrot en zwartbenigheid }\end{array}$ & $10 \%$ & $50 \%$ & 8 & 11 & 13 \\
\hline & Natte periode & $\begin{array}{l}\text { Ten minste } 75 \% \text { van } 21 \text { dagen met een dagelijkse neerslag } \geq \\
0,5 \mathrm{~mm}\end{array}$ & Jun-Sep & $\begin{array}{l}\text { Niet mogelijk om te spuiten tegen } \\
\text { Fytoftora infestans }\end{array}$ & $50 \%$ & $100 \%$ & 22 & -1 & -10 \\
\hline & Natte periode & $\begin{array}{l}\text { Ten minste } 75 \% \text { van } 21 \text { dagen met een dagelijkse neerslag } \geq \\
0,5 \mathrm{~mm}\end{array}$ & Aug-Okt & Schade aan de knollen & $0 \%$ & $0 \%$ & 20 & 0 & -8 \\
\hline \multirow[t]{5}{*}{ Zomergerst $^{2}$} & Droge periode & Minimaal 40 dagen met een neerslagsom $\leq 10 \mathrm{~mm}$ & Jun-Aug & Lagere graanopbrengst & $10 \%$ & $50 \%$ & 1 & 0 & 2 \\
\hline & Natte periode & $\begin{array}{l}\text { Ten minste } 75 \% \text { van } 21 \text { dagen met een dagelijkse neerslag } \geq \\
0,5 \mathrm{~mm}\end{array}$ & Apr-Mei & Roest en Septoria & $25 \%$ & $75 \%$ & 3 & 1 & 3 \\
\hline & Natte periode & $\begin{array}{l}\text { Ten minste } 75 \% \text { van } 21 \text { dagen met een dagelijkse neerslag } \geq \\
0,5 \mathrm{~mm}\end{array}$ & Mei-Jul & $\begin{array}{l}\text { Roest, Fusarium en Septoria en een } \\
\text { lagere kwaliteit }\end{array}$ & $25 \%$ & $75 \%$ & 14 & 0 & -4 \\
\hline & Hevige neerslag & Dagelijkse neerslag $\geq 45 \mathrm{~mm}$ & Mei-Aug & Niet mogelijk om te oogsten & $0 \%$ & $0 \%$ & 1 & 1 & 1 \\
\hline & Natte periode & $\begin{array}{l}\text { Ten minste } 75 \% \text { van } 21 \text { dagen met een dagelijkse neerslag } \geq \\
0,5 \mathrm{~mm}\end{array}$ & Jul-Sep & Niet mogelijk om te oogsten & $10 \%$ & $75 \%$ & 18 & -1 & -10 \\
\hline \multirow[t]{5}{*}{ Suikerbieten } & Droge periode & Minimaal 30 dagen met een neerslagsom $\leq 5 \mathrm{~mm}$ & Mrt-Apr & Opkomstproblemen & $25 \%$ & $35 \%$ & 2 & 0 & 0 \\
\hline & Natte periode & $\begin{array}{l}\text { Minimaal } 10 \% \text { van } 28 \text { dagen met een neerslagpercentage } \geq 10 \\
\mathrm{~mm}\end{array}$ & Aug-Sep & Lagere suiker inhoud & $10 \%$ & $25 \%$ & 31 & 4 & 1 \\
\hline & Natte periode & $\begin{array}{l}\text { Minimaal } 75 \% \text { van } 14 \text { dagen met een dagelijkse neerslag } \geq 0,5 \\
\mathrm{~mm}\end{array}$ & Apr-Jul & Natte condities veroorzaken Rhizomania & $10 \%$ & $50 \%$ & 27 & 2 & -6 \\
\hline & Warme winter & Minimaal 14 dagen met een maximumtemperatuur $\geq 10^{\circ} \mathrm{C}$ & Dec-Mrt & In opslag verliezen bieten suiker inhoud & $10 \%$ & $25 \%$ & 1 & 1 & 12 \\
\hline & Nachtvorst & Minimaal 1 dag met een minimumtemperatuur $\leq-3^{\circ} \mathrm{C}$ & Mrt-Apr & Bevriezen zaailingen & $10 \%$ & $20 \%$ & 67 & -30 & -30 \\
\hline \multirow[t]{5}{*}{ Zaaiuien } & Droge periode & Minimaal 30 dagen met een neerslagsom $\leq 5 \mathrm{~mm}$ & Feb-Apr & Droogteschade zaailingen & $0 \%$ & $100 \%$ & 3 & 0 & 0 \\
\hline & Droge periode & Minimaal 30 dagen met een neerslagsom $\leq 10 \mathrm{~mm}$ & Jun-Jul & Droogteschade & $30 \%$ & $40 \%$ & 2 & 0 & 5 \\
\hline & Hevige neerslag & Dagelijkse neerslag van $\geq 45 \mathrm{~mm}$ of in 8 dagen $\geq 100 \mathrm{~mm}$ & Sep-Okt & $\begin{array}{l}\text { Bacteriën infecteren bladeren (via } \\
\text { bodemdeeltjes) }\end{array}$ & $0 \%$ & $100 \%$ & 1 & 1 & 5 \\
\hline & Hevige neerslag & Dagelijkse neerslag $\geq 45 \mathrm{~mm}$ & Jul-Aug & Schimmels infecteren bladeren & $10 \%$ & $50 \%$ & 1 & 1 & 1 \\
\hline & Warm en nat & $\begin{array}{l}\text { Minimaal } 14 \text { dagen met een maximumtemperatuur } \geq 20^{\circ} \mathrm{C} \text { en } \\
\text { gedurende } 50 \% \text { van de dagen een neerslag } \geq 0,5 \mathrm{~mm}\end{array}$ & Jun-Aug & Schimmelinfecties & $50 \%$ & $60 \%$ & 8 & 13 & 16 \\
\hline
\end{tabular}

${ }^{1}$ Verwachte verandering $(\Delta)$ van de frequenties onder de KNMI-klimaatscenario's (GL 2050 en WH 2050) t.o.v. de referentieperiode 1981 -2010

${ }^{2}$ De klimaatfactoren voor zomergerst zijn gebaseerd en aangepast op die van wintertarwe. Zo zijn de klimaatfactoren die in de winter in wintertarwe spelen, er bij zomergerst uitgehaald. 
Uit Tabel 3 blijkt dat naar verwachting voor de meeste klimaatfactoren en klimaatscenario's een verandering gaat optreden van de frequenties. Voor zetmeelaardappelen valt op dat de klimaatfactoren hittegolf ( $\Delta \mathrm{G}_{\mathrm{L}}$ $\left.W_{H}=[8 ; 22]\right)$ en warm en nat $\left(\Delta G_{L}-W_{H}=[11 ; 13]\right)$ onder beide scenario's sterk toenemen. De frequenties van de klimaatfactor natte periode $\left(\Delta \mathrm{G}_{\mathrm{L}}-\mathrm{W}_{\mathrm{H}}=[-1 ;-10]\right)$ in de zomer nemen naar verwachting in beide scenario's af. Bij zomergerst zijn de toenames geringer, zo neemt natte periode $\left(\Delta G_{L}-W_{H}=[1 ; 3]\right)$ en hevige neerslag $\left(\Delta G_{L}-W_{H}=[1 ; 1]\right)$ toe. Daarnaast neemt de klimaatfactor natte periode (juli - september) $\left(\Delta G_{L}-W_{H}=[-1 ;-10]\right)$ af. Voor suikerbieten zijn de verschillen tussen stijgingen en dalingen groter, zo nemen frequenties van warme winter $\left(\Delta \mathrm{G}_{\mathrm{L}}-\mathrm{W}_{\mathrm{H}}=[1 ; 12]\right)$ toe en nemen de frequenties van nachtvorst $(\Delta$ $\left.G_{L}-W_{H}=[-30 ;-30]\right)$ sterk af. Van de klimaatfactoren van zaaiuien laat met name warm en nat $\left(\Delta G_{L}-W_{H}=\right.$ $[13 ; 16])$ in de zomer een forse stijging zien, de overige klimaatfactoren nemen niet of matig toe.

\section{Stap 3 Risico's}

De risico's als gevolg van een veranderende frequentie door klimaatverandering van de klimaatfactoren, zijn inzichtelijk gemaakt in Tabel 4. De hedendaagse bruto geldopbrengst van een gewas is als uitgangspunt genomen en geïndexeerd op 100. Per klimaatfactor is het effect van een toe of afnemend risico te zien, uitgedrukt in effect op index van de bruto geldopbrengst. Dat is gedaan voor de twee scenario's in $2050\left(G_{L}\right.$ en $W_{H}$ ) en voor de lage en hoge impact inschatting van een klimaatfactor. Deze impacts per event blijven in de toekomst gelijk, maar de frequenties kunnen veranderen, waardoor dus ook het risico verandert.

Tabel 4 Geïndexeerde effecten van risico's voor klimaatscenario's en impact (laag en hoog) ten opzichte van referentieperiode per klimaatfactor voor een akkerbouwbedrijf in de Veenkoloniën.

\begin{tabular}{|c|c|c|c|c|c|c|}
\hline Gewas & Klimaatfactor & Ref. periode & GL 2050 laag & GL 2050 hoog & WH 2050 laag & WH 2050 hoog \\
\hline \multirow[t]{4}{*}{ Zetmeelaardappelen } & Natte periode & 100 & 100 & 100 & 100 & 100 \\
\hline & Hevige neerslag & 100 & 99 & 98 & 98 & 95 \\
\hline & Warm en nat & 100 & 96 & 82 & 96 & 78 \\
\hline & Natte periode & 100 & 102 & 103 & 117 & 133 \\
\hline \multirow{4}{*}{ Zomergerst } & Natte periode & 100 & 99 & 98 & 98 & 93 \\
\hline & Natte periode & 100 & 100 & 100 & 103 & 110 \\
\hline & Hevige neerslag & 100 & 100 & 100 & 100 & 100 \\
\hline & Natte periode & 100 & 100 & 103 & 103 & 125 \\
\hline \multirow{2}{*}{ Suikerbieten } & Warme winter & 100 & 100 & 99 & 96 & 90 \\
\hline & Nachtvorst & 100 & 110 & 120 & 110 & 120 \\
\hline \multirow[t]{5}{*}{ Zaaiuien } & Droge periode & 100 & 100 & 100 & 100 & 100 \\
\hline & Droge periode & 100 & 100 & 100 & 95 & 93 \\
\hline & Hevige neerslag & 100 & 100 & 97 & 100 & 83 \\
\hline & Hevige neerslag & 100 & 100 & 98 & 100 & 98 \\
\hline & Warm en nat & 100 & 78 & 74 & 73 & 68 \\
\hline
\end{tabular}

Een daling of stijging van de indexen van de individuele klimaatfactoren in Tabel 4 valt samen met een daling of stijging van de hiervoor beschreven frequenties en de hoogte van de impact uit Tabel 3 . Voor zetmeelaardappelen valt op dat de indexen van de klimaatfactoren hittegolf ( $\Delta \mathrm{G} \mathrm{L}$ laag - hoog= [93; $80], W_{H}$ laag - hoog $\left.=[82 ; 45]\right)$ en warm en nat $\left(\Delta \mathrm{GL}\right.$ laag - hoog $=[96 ; 82], W_{H}$ laag - hoog $=[96 ;$ $78]$ ) onder beide scenario's sterk dalen. Het risico voor de klimaatfactor natte periode ( $\Delta \mathrm{GL}$ laag hoog $=[102 ; 103], W_{H}$ laag - hoog $\left.=[117 ; 133]\right)$ in de zomer neemt naar verwachting in beide scenario's af. Bij zomergerst zijn de veranderingen van de indexen geringer, zo neemt de index van natte periode in april en mei in beide scenario's af ( $\Delta \mathrm{G}_{L}$ laag - hoog $=[99 ; 98], W_{H}$ laag - hoog= $[98$; 93]). De indexen van natte periode in de zomer ( $\Delta G_{L}$ laag - hoog $=[100 ; 103], W_{H}$ laag - hoog= [103; 125]) stijgen in beide klimaatscenario's (op GL laag na). Voor suikerbieten zijn de verschillen tussen de stijgingen en dalingen van de indexen groter. Naar verwachting nemen de indexen van de klimaatfactor warme winter af $\left(\Delta \mathrm{G}_{\mathrm{L}}\right.$ laag - hoog $=[100 ; 99], \mathrm{W}_{\mathrm{H}}$ laag - hoog= $\left.[96 ; 90]\right)$ en nemen de indexen van nachtvorst toe $\left(\Delta \mathrm{G}\right.$ laag - hoog $=[110 ; 120], W_{H}$ laag - hoog $\left.=[110 ; 120]\right)$. Van de 
indexen van zaaiuien laat met name de klimaatfactor warm en nat ( $\Delta \mathrm{GL}$ laag - hoog= $[78 ; 74], W_{H}$ laag - hoog $=[73 ; 68]$ ) een daling zien, de overige indexen veranderen niet of matig.

\section{Stap 4 Betekenis bedrijf}

Om de individuele risico's van klimaatfactoren per gewas op te schalen naar bedrijfsniveau, wordt gekeken naar de bouwplan bruto geldopbrengst. De bouwplan bruto geldopbrengst is een gewogen gemiddelde van de bruto geldopbrengst van de gewassen, naar hun aandeel in het bouwplan. In dit voorbeeldbedrijf van 100 hectare, is 50\% zetmeelaardappel, $20 \%$ zomergerst, $25 \%$ suikerbiet en $5 \%$ zaai-ui. Hoe groter het aandeel van een gewas, hoe groter de bijdrage daarvan aan de bouwplan bruto geldopbrengst. De bouwplan bruto geldopbrengst is hier berekend op €3004 per hectare per jaar.

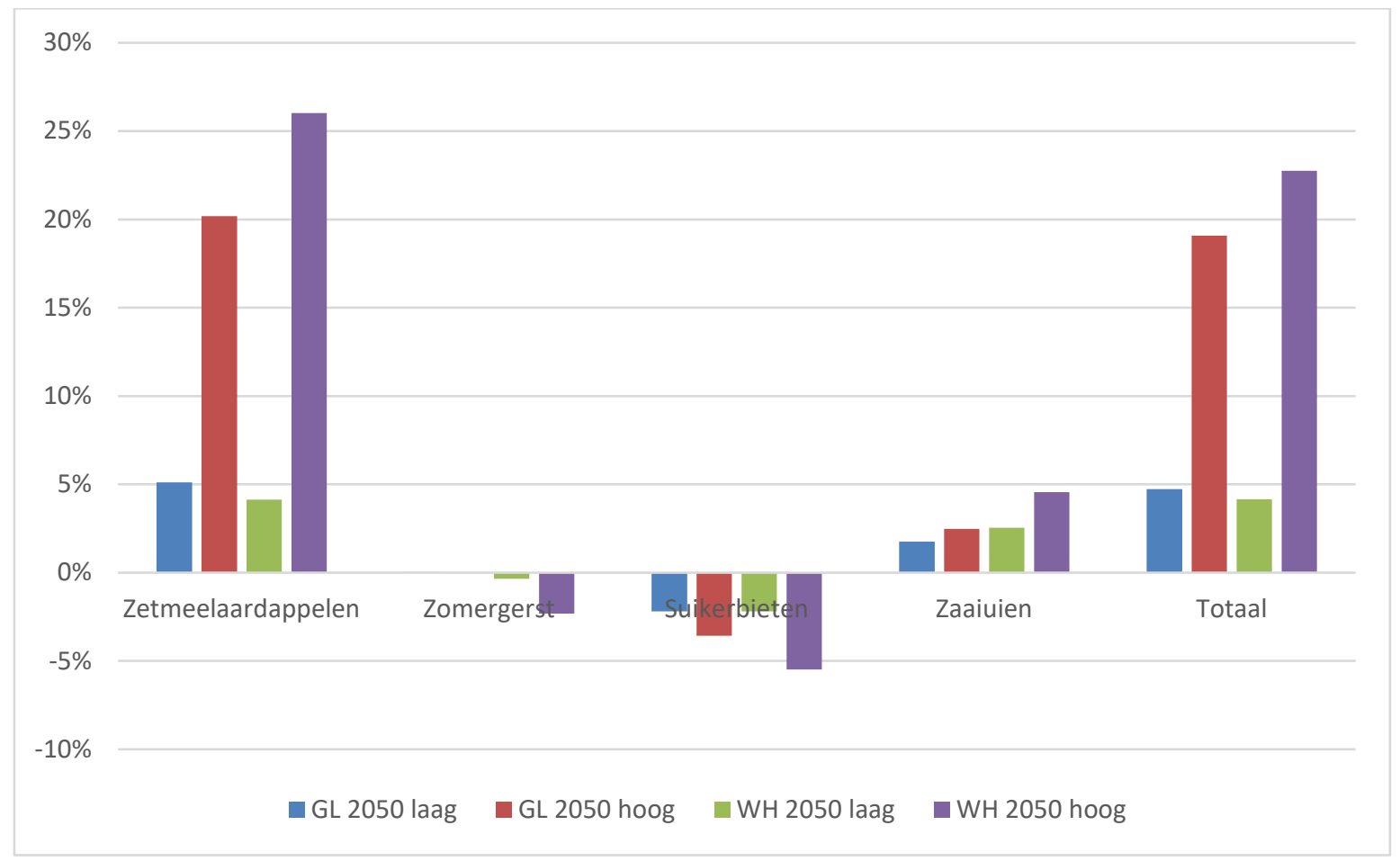

Figuur 3 Risico van klimaatverandering per gewas als percentage van de bouwplan bruto geldopbrengst in de Veenkoloniën.

Figuur 3 toont per gewas het risico als percentage van de bouwplan bruto geldopbrengst per hectare. Dit is een gewogen gemiddelde, dus hoe groter het aandeel van het gewas, hoe groter de bijdrage aan het bouwplan risico van dat gewas zal zijn. De laatste kolom toont het totale bedrijfsrisico.

In Figuur 3 is te zien dat het totale bedrijfsrisico door klimaatverandering in dit bouwplan toeneemt ( $\Delta$ $\mathrm{GL}_{\mathrm{L}}$ laag - hoog $=[5 \% ; 19 \%], \mathrm{W}_{\mathrm{H}}$ laag $\left.-\mathrm{hoog}=[4 \% ; 23 \%]\right)$. Wat verder opvalt is dat zetmeelaardappelen, in elk scenario, het grootste risico met zich meebrengen in de toekomst ( $\Delta \mathrm{GL}$ laag - hoog $=[5 \% ; 20 \%], W_{H}$ laag - hoog $\left.=[4 \% ; 26 \%]\right)$. Dit is te verklaren doordat zetmeelaardappelen gevoelig zijn voor weersextremen (met name voor hittegolven met doorwas) en heeft daarbij een belangrijk aandeel in het bouwplan. Ook voor het gewas zaaiuien ( $\Delta \mathrm{G} \mathrm{L}$ laag - hoog= $[2 \% ; 2 \%], W_{H}$ laag - hoog $\left.=[3 \% ; 5 \%]\right)$ neemt het risico van weersextremen door klimaatverandering toe. Voor gewassen als zomergerst en suikerbieten neemt in de toekomst, voornamelijk door warmere winters, het risico juist iets af.

De toename van het risico is sterk afhankelijk van het klimaatscenario en de impact (laag of hoog). Naast de vastgestelde klimaatfactoren, kunnen telers door warmere winters vaker te maken krijgen met aardappelopslag, dit kan leiden tot de aantrekking van aaltjes en een bron vormen van Fytoftora. De laatstgenoemde kan met effectieve bespuitingen tegengegaan worden. Ook de coloradokever zal naar verwachting vaker voorkomen door de stijging van de temperaturen in de winters en hierdoor meer problemen geven in het groeiseizoen. Daarnaast kunnen bladluizen tijdens het groeiseizoen door hogere temperaturen een groter risico vormen in virusoverdracht wat vervolgens tot hogere afkeuring kan leiden. Het is van belang dat telers hiertegen effectieve middelen blijven inzetten en ontwikkelen. 
Tijdens de oogst kunnen door te natte omstandigheden natte plekken ontstaan waardoor er niet meer geoogst kan worden omdat de draagkracht ontbreekt. De schade hiervan is onbekend.

De klimaatscenario's $G_{L}$ en $W_{H}$ laten beide een toename van het aantal weersextremen zien. Hoewel er verschil zit in de mate waarin individuele klimaatfactoren een risico gaan vormen in de toekomst, laten beide scenario's een overwegende toename van natte, warme en droge weersextremen zien, de klimaatfactoren welke door lage temperaturen worden bepaald laten een afname. Bij adaptatiemaatregelen is het dus belangrijk om te kijken naar maatregelen die voor meerdere situaties effectief kunnen zijn (zoals goede bodemstructuur en peil gestuurde drainage). Veel van deze maatregelen zullen soms al zijn uitgevoerd op het boerenbedrijf. Daarom kan het ook van belang zijn om te kijken naar rassenkeus.

\subsection{Akkerbouwbedrijf Zeeland}

Hieronder worden, per stap(pen) van de methodiek, de resultaten van een akkerbouwbedrijf in Zeeland gepresenteerd.

\section{Stap 1 Het bedrijf}

- $\quad$ Gewassen in bedrijf (totaal 75 ha):

- Consumptieaardappelen $25 \%$ van areaal

- Bruto geldopbrengst $€ 6.876$, Consumptieaardappelen, kleigrond, Zuidwest Nederland (van der Voort 2018)

- Wintertarwe $42,5 \%$ van areaal

- Bruto geldopbrengst $€ 2.143$, Wintertarwe, kleigrond, Zuidwest Nederland, IJsselmeerpolders (van der Voort 2018)

- Suikerbieten $20 \%$ van areaal

- Bruto geldopbrengst $€ 3.831$, Suikerbieten, kleigrond, Zuidwest Nederland (van der Voort 2018)

- Zaaiuien $12,5 \%$ van areaal

- Bruto geldopbrengst $€ 5.050$, Zaaiuien, kleigrond, Zuidwest Nederland (van der Voort 2018)

- Weerstation: Vlissingen

\section{Stap 2 De klimaatfactoren}

De klimaatfactoren, hun meteorologische definitie, periode, type impact en economische impact van het bouwplan zijn hieronder in tabelvorm getoond (Tabel 5), met hun klimatologische definitie, periode van kwetsbaarheid voor het gewas, de type impact bij optreden, de economische impact (als percentage van de bruto geldopbrengst (k的rijs) en de frequenties per 30 jaar voor de huidige situatie (1981-2010) en de frequentie verandering in de twee toekomstscenario GL en WH (20362065). 


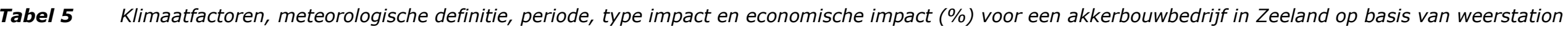
Vlissingen.

\begin{tabular}{|c|c|c|c|c|c|c|c|c|c|}
\hline Gewas & Klimaatfactor & Meteorologische definitie & $\begin{array}{l}\text { Periode van } \\
\text { kwetsbaarheid }\end{array}$ & Type impact & $\begin{array}{l}\text { Impact } \\
\text { laag }\end{array}$ & $\begin{array}{l}\text { Impact } \\
\text { hoog }\end{array}$ & $\begin{array}{l}\text { Frequentie } \\
\text { heden }\end{array}$ & $\begin{array}{l}\Delta G_{L} \\
2050^{1}\end{array}$ & $\begin{array}{l}\Delta W_{H} \\
2050^{1}\end{array}$ \\
\hline \multirow{6}{*}{ Consumptieaardappelen } & Natte periode & Ten minste $75 \%$ van 21 dagen met een dagelijkse neerslag $\geq 0,5 \mathrm{~mm}$ & Okt-Apr & Ploegen en voorbereiding zaaibed & $0 \%$ & $0 \%$ & 37 & 2 & 8 \\
\hline & Hevige neerslag & Dagelijkse neerslag $\geq 45 \mathrm{~mm}$ of in 3 dagen $\geq 60 \mathrm{~mm}$ & Mei-Sep & Rotten van knollen & $25 \%$ & $75 \%$ & 9 & 4 & 5 \\
\hline & Hittegolf & Minimaal 3 dagen $\geq 30^{\circ} \mathrm{C}$ in een periode van minimaal 5 dagen $\geq 25^{\circ} \mathrm{C}$ & Jul-Sep & Doorwas en opbrengstderving & $25 \%$ & $75 \%$ & 1 & 7 & 21 \\
\hline & Warm en nat & $\begin{array}{l}\text { Minimaal } 14 \text { dagen met een maximumtemperatuur } \geq 20^{\circ} \mathrm{C} \text { en gedurende } \\
50 \% \text { van de dagen een neerslag } \geq 0,5 \mathrm{~mm}\end{array}$ & Jul-Sep & $\begin{array}{l}\text { Pectobacterium en Dickeya } \\
\text { veroorzakers van natrot en } \\
\text { zwartbenigheid }\end{array}$ & $10 \%$ & $50 \%$ & 3 & 4 & 20 \\
\hline & Natte periode & Ten minste $75 \%$ van 21 dagen met een dagelijkse neerslag $\geq 0,5 \mathrm{~mm}$ & Jun-Sep & $\begin{array}{l}\text { Niet mogelijk om te spuiten tegen } \\
\text { Fytoftora infestans }\end{array}$ & $50 \%$ & $100 \%$ & 16 & -1 & -7 \\
\hline & Natte periode & Ten minste $75 \%$ van 21 dagen met een dagelijkse neerslag $\geq 0,5 \mathrm{~mm}$ & Aug-Okt & Schade aan de knollen & $0 \%$ & $0 \%$ & 13 & 0 & -3 \\
\hline \multirow[t]{7}{*}{ Wintertarwe } & Natte periode & Ten minste $75 \%$ van 21 dagen met een dagelijkse neerslag $\geq 0,5 \mathrm{~mm}$ & Okt-Dec & Uitgestelde zaaidatum & $0 \%$ & $0 \%$ & 16 & 0 & 3 \\
\hline & $\begin{array}{l}\text { Vriezen en } \\
\text { dooien }\end{array}$ & $\begin{array}{l}\text { Periode van minimaal } 3 \text { dagen herhaalde vorst en ontdooien (minimum } \leq- \\
1^{\circ} \mathrm{C} \text { en maximum } \geq 1^{\circ} \mathrm{C} \text { ) na periode van sterke vorst (minimum } \leq-10^{\circ} \mathrm{C} \text { ), } \\
\text { incl. een overgangsperiode van } 2 \text { dagen naar ontdooien. }\end{array}$ & Nov-Mrt & Wortelschade & $10 \%$ & $50 \%$ & 0 & 0 & 0 \\
\hline & Droge periode & Minimaal 40 dagen met een neerslagsom $\leq 10 \mathrm{~mm}$ & Jun-Aug & Lagere graanopbrengst & $10 \%$ & $50 \%$ & 5 & 0 & 1 \\
\hline & Natte periode & Ten minste $75 \%$ van 21 dagen met een dagelijkse neerslag $\geq 0,5 \mathrm{~mm}$ & Apr-Mei & Roest en Septoria & $25 \%$ & $75 \%$ & 4 & 0 & 0 \\
\hline & Natte periode & Ten minste $75 \%$ van 21 dagen met een dagelijkse neerslag $\geq 0,5 \mathrm{~mm}$ & Mei-Jul & $\begin{array}{l}\text { Roest, Fusarium en Septoria en } \\
\text { een lagere kwaliteit }\end{array}$ & $25 \%$ & $75 \%$ & 10 & -1 & -5 \\
\hline & Hevige neerslag & Dagelijkse neerslag $\geq 45 \mathrm{~mm}$ & Mei-Aug & Niet mogelijk om te oogsten & $0 \%$ & $0 \%$ & 7 & 1 & 3 \\
\hline & Natte periode & Ten minste $75 \%$ van 21 dagen met een dagelijkse neerslag $\geq 0,5 \mathrm{~mm}$ & Jul-Sep & Niet mogelijk om te oogsten & $10 \%$ & $75 \%$ & 12 & 0 & -5 \\
\hline \multirow[t]{5}{*}{ Suikerbieten } & Droge periode & Minimaal 30 dagen met een neerslagsom $\leq 5 \mathrm{~mm}$ & Mrt-Apr & Opkomstproblemen & $25 \%$ & $35 \%$ & 1 & 0 & 0 \\
\hline & Natte periode & Minimaal $10 \%$ van 28 dagen met een neerslagpercentage $\geq 10 \mathrm{~mm}$ & Aug-Sep & Lagere suiker inhoud & $10 \%$ & $25 \%$ & 27 & 0 & -1 \\
\hline & Natte periode & Minimaal $75 \%$ van 14 dagen met een dagelijkse neerslag $\geq 0,5 \mathrm{~mm}$ & Apr-Jul & $\begin{array}{l}\text { Natte condities veroorzaken } \\
\text { Rhizomania }\end{array}$ & $10 \%$ & $50 \%$ & 25 & 1 & -6 \\
\hline & Warme winter & Minimaal 14 dagen met een maximumtemperatuur $\geq 10^{\circ} \mathrm{C}$ & Dec-Mrt & $\begin{array}{l}\text { In opslag verliezen bieten suiker } \\
\text { inhoud }\end{array}$ & $10 \%$ & $25 \%$ & 1 & 3 & 21 \\
\hline & Nachtvorst & Minimaal 1 dag met een minimumtemperatuur $\leq-3^{\circ} \mathrm{C}$ & Mrt-Apr & Bevriezen zaailingen & $10 \%$ & $20 \%$ & 7 & -7 & -7 \\
\hline \multirow[t]{5}{*}{ Zaaiuien } & Droge periode & Minimaal 30 dagen met een neerslagsom $\leq 5 \mathrm{~mm}$ & Feb-Apr & Droogteschade zaailingen & $0 \%$ & $100 \%$ & 1 & 0 & 0 \\
\hline & Droge periode & Minimaal 30 dagen met een neerslagsom $\leq 10 \mathrm{~mm}$ & Jun-Jul & Droogteschade & $30 \%$ & $40 \%$ & 5 & 1 & 6 \\
\hline & Hevige neerslag & Dagelijkse neerslag van $\geq 45 \mathrm{~mm}$ of in 8 dagen $\geq 100 \mathrm{~mm}$ & Sep-Okt & $\begin{array}{l}\text { Bacteriën infecteren bladeren (via } \\
\text { bodemdeeltjes) }\end{array}$ & $0 \%$ & $100 \%$ & 3 & 1 & 0 \\
\hline & Hevige neerslag & Dagelijkse neerslag $\geq 45 \mathrm{~mm}$ & Jul-Aug & Schimmels infecteren bladeren & $10 \%$ & $50 \%$ & 6 & 1 & 3 \\
\hline & Warm en nat & $\begin{array}{l}\text { Minimaal } 14 \text { dagen met een maximumtemperatuur } \geq 20^{\circ} \mathrm{C} \text { en gedurende } \\
50 \% \text { van de dagen een neerslag } \geq 0,5 \mathrm{~mm}\end{array}$ & Jun-Aug & Schimmelinfecties & $50 \%$ & $60 \%$ & 3 & 4 & 20 \\
\hline
\end{tabular}

${ }^{1}$ Verwachte verandering $(\Delta)$ van de frequenties onder de KNMI-klimaatscenario's (GL 2050 en $W_{H}$ 2050) t.o.v. de referentieperiode 1981-2010 
Uit Tabel 5 blijkt dat naar verwachting voor de meeste klimaatfactoren en klimaatscenario's een verandering gaat optreden van de frequenties. Voor consumptieaardappelen valt op dat de klimaatfactoren hittegolf $\left(\Delta \mathrm{G}_{\mathrm{L}}-\mathrm{W}_{\mathrm{H}}=[7 ; 21]\right)$ en warm en nat $\left(\Delta \mathrm{G}_{\mathrm{L}}-\mathrm{W}_{\mathrm{H}}=[4 ; 20]\right)$ onder beide scenario's sterk toenemen. De frequenties van de klimaatfactor natte periode $\left(\Delta G_{L}-W_{H}=[-1 ;-7]\right)$ in de zomer nemen naar verwachting in beide scenario's af. Bij wintertarwe zijn de toenames geringer, zo neemt alleen hevige neerslag $\left(\Delta \mathrm{G}_{\mathrm{L}}-\mathrm{W}_{\mathrm{H}}=[1 ; 3]\right)$ in beide klimaatscenario's toe. Daarnaast neemt de klimaatfactor natte periode (mei - juni) $\left(\Delta \mathrm{G}_{\mathrm{L}}-\mathrm{W}_{\mathrm{H}}=[-1 ;-5]\right)$ af. Voor suikerbieten zijn de verschillen tussen stijgingen en dalingen groter, zo nemen frequenties van warme winter $\left(\Delta \mathrm{G}_{\mathrm{L}}-\mathrm{W}_{\mathrm{H}}=\right.$ $[3 ; 21])$ toe en nemen de frequenties van nachtvorst $\left(\Delta \mathrm{G}_{\mathrm{L}}-\mathrm{W}_{\mathrm{H}}=[-7 ;-7]\right)$ af. Van de klimaatfactoren van zaaiuien laat met name warm en nat $\left(\Delta G_{L}-W_{H}=[4 ; 20]\right)$ in de zomer een forse stijging zien, de overige klimaatfactoren nemen niet of matig toe.

\section{Stap 3 Risico's}

De risico's als gevolg van een veranderende frequentie door klimaatverandering van de klimaatfactoren, zijn inzichtelijk gemaakt in Tabel 6. De hedendaagse bruto geldopbrengst van een gewas is als uitgangspunt genomen en geïndexeerd op 100. Per klimaatfactor is het effect van een toe of afnemend risico te zien, uitgedrukt in effect op index van de bruto geldopbrengst. Dat is gedaan voor de twee scenario's in $2050\left(G_{L}\right.$ en $W_{H}$ ) en voor de lage en hoge impact inschatting van een klimaatfactor. Deze impacts per event blijven in de toekomst gelijk, maar de frequenties kunnen veranderen, waardoor dus ook het risico verandert.

Tabel 6 Geïndexeerde effecten van risico's voor klimaatscenario's en impact (laag en hoog) ten opzichte van referentieperiode per klimaatfactor voor een akkerbouwbedrijf in Zeeland.

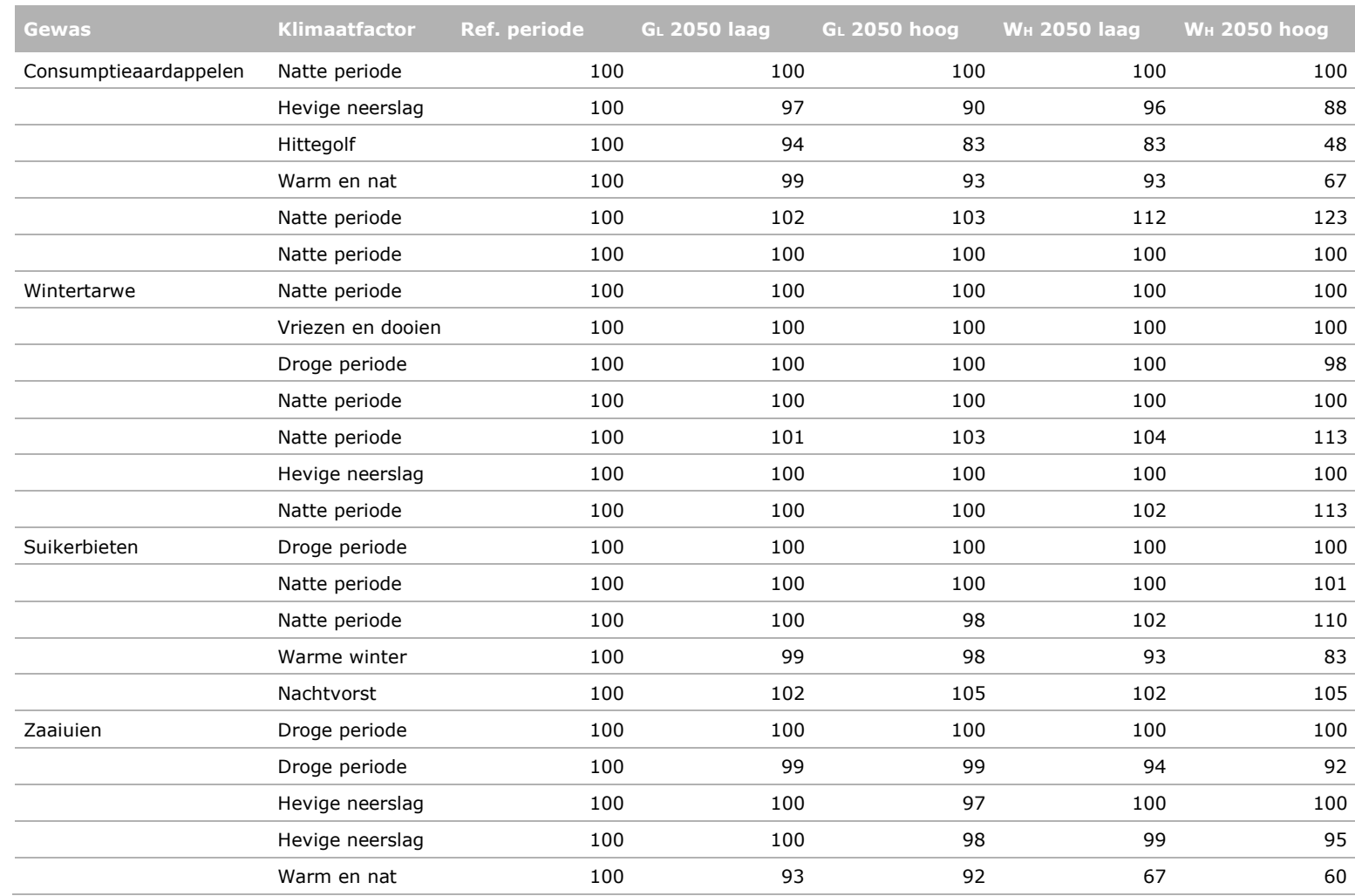

Voor consumptieaardappelen valt op dat de indexen van de klimaatfactoren hittegolf ( $\Delta \mathrm{G}_{\mathrm{L}}$ laag hoog $=[94 ; 83], W_{H}$ laag - hoog $\left.=[83 ; 48]\right)$ en warme winter $\left(\Delta G_{L}\right.$ laag - hoog $=[98 ; 93], W_{H}$ laag hoog $=[83 ; 48])$ onder beide scenario's sterk dalen. Het risico voor de klimaatfactor natte periode $(\Delta$ $\mathrm{GL}$ laag - hoog $=[102 ; 103], W_{H}$ laag - hoog $\left.=[112 ; 123]\right)$ in de zomer neemt naar verwachting in beide scenario's af. Bij wintertarwe zijn de veranderingen van de indexen geringer, zo neemt de index van droge periode in het $\mathrm{W}_{\mathrm{H}}$-scenario (hoog) af $\left(\Delta \mathrm{W}_{\mathrm{H}}\right.$ laag - hoog $\left.=[100 ; 98]\right)$. De indexen van natte periode (mei-juni) $\left(\Delta \mathrm{G}\right.$ laag - hoog $=[101 ; 103], W_{H}$ laag - hoog $\left.=[104 ; 113]\right)$ stijgen in beide klimaatscenario's. Voor suikerbieten zijn de verschillen tussen de stijgingen en dalingen van de indexen groter. Naar verwachting nemen de indexen van de klimaatfactor warme winter af ( $\Delta \mathrm{G}_{\mathrm{L}}$ laag - hoog $=[99 ; 98], W_{H}$ laag - hoog $\left.=[93 ; 83]\right)$ en nemen de indexen van nachtvorst toe $\left(\Delta G_{L}\right.$ laag - 
hoog $=[102 ; 105], W_{H}$ laag - hoog $\left.=[102 ; 105]\right)$. Van de indexen van zaaiuien laat met name de klimaatfactor warm en nat $\left(\Delta \mathrm{G}_{\mathrm{L}}\right.$ laag - hoog $=[93 ; 92], \mathrm{W}_{\mathrm{H}}$ laag - hoog $\left.=[67 ; 60]\right)$ een daling zien, de overige indexen veranderen niet of matig.

\section{Stap 4 Betekenis bedrijf}

Om de individuele risico's van klimaatfactoren per gewas op te schalen naar bedrijfsniveau, wordt gekeken naar de bouwplan bruto geldopbrengst. De bouwplan bruto geldopbrengst is een gewogen gemiddelde van de bruto geldopbrengst van de gewassen, naar hun aandeel in het bouwplan. In dit voorbeeldbedrijf van 75 hectare, is $25 \%$ consumptieaardappel, $42,5 \%$ wintertarwe, $20 \%$ suikerbiet en $12,5 \%$ zaai-ui. Hoe groter het aandeel van een gewas, hoe groter de bijdrage daarvan aan de bouwplan bruto geldopbrengst. De bouwplan bruto geldopbrengst is hier berekend op €4027 per hectare per jaar.

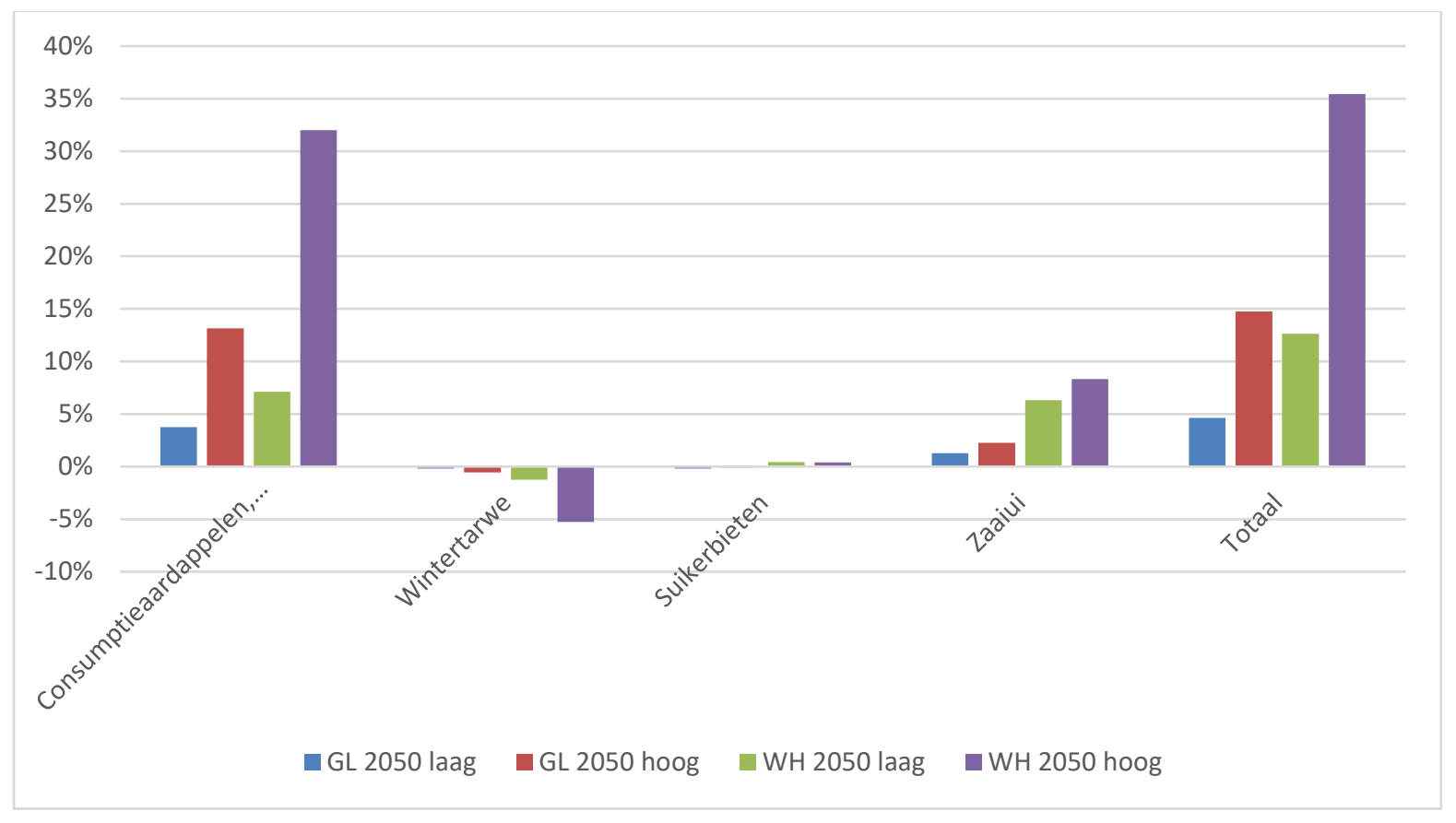

Figuur 4 Risico van klimaatverandering per gewas als percentage van de bouwplan bruto geldopbrengst in Zeeland.

Figuur 4 toont per gewas het risico als percentage van de bouwplan bruto geldopbrengst per hectare. Dit is een gewogen gemiddelde, dus hoe groter het aandeel van het gewas, hoe groter de bijdrage aan het bouwplan risico van dat gewas zal zijn. De laatste kolom toont het totale bedrijfsrisico.

In Figuur 4 is te zien dat het totale bedrijfsrisico door klimaatverandering in dit bouwplan toeneemt ( $\Delta$ $\mathrm{GL}_{\mathrm{L}}$ laag - hoog $=[5 \% ; 15 \%], \mathrm{W}_{\mathrm{H}}$ laag - hoog $\left.=[13 \% ; 35 \%]\right)$. Wat verder opvalt is dat consumptieaardappelen, in elk scenario, het grootste risico met zich meebrengen in de toekomst ( $\Delta \mathrm{G}_{\mathrm{L}}$ laag - hoog $=[4 \% ; 13 \%], W_{H}$ laag - hoog $\left.=[7 \% ; 32 \%]\right)$. Dit is te verklaren doordat consumptieaardappelen gevoelig zijn voor weersextremen, met name voor warme periodes met doorwas. Ook voor het gewas zaai-ui $\left(\Delta \mathrm{G}\right.$ laag - hoog $=[1 \% ; 2 \%], W_{H}$ laag - hoog= $\left.[6 \% ; 8 \%]\right)$ neemt het risico van weersextremen door klimaatverandering toe. Voor gewassen als wintertarwe neemt in de toekomst, voornamelijk door warmere winters, het risico juist iets af. Het risico voor suikerbieten blijft in beide klimaatscenario's nihil.

De toename van het risico is sterk afhankelijk van het klimaatscenario en de impact (laag of hoog). Naast de vastgestelde klimaatfactoren, kunnen telers door warmere winters vaker te maken krijgen met aardappelopslag, dit kan leiden tot de aantrekking van aaltjes en een bron vormen van Fytoftora. De laatstgenoemde kan met effectieve bespuitingen tegengegaan worden. Ook de coloradokever zal naar verwachting vaker voorkomen door de stijging van de temperaturen in de winters en hierdoor meer problemen geven in het groeiseizoen. Daarnaast kunnen bladluizen tijdens het groeiseizoen door hogere temperaturen een groter risico vormen in virusoverdracht wat vervolgens tot hogere afkeuring 
kan leiden. Het is van belang dat telers hiertegen effectieve middelen blijven inzetten en ontwikkelen. Door de inklinkende bodem en een stijgende zeespiegel ontstaat er een steeds grotere opwaartse druk van zout water (verzilting). Door verzilting wordt het steeds moeilijker om het grondwater zoet te houden. Dit effect wordt versterkt in droge jaren, zo zijn er afgelopen jaren regelmatig percelen uien niet geoogst omdat de schade te groot was. De verzilting is niet opgenomen in de ACC noch de stresstest als klimaatfactor, maar zal naar verwachting een groter probleem vormen.

De klimaatscenario's $G_{L}$ en $W_{H}$ laten beide een toename van het aantal weersextremen zien. Hoewel er verschil zit in de mate waarin individuele klimaatfactoren een risico gaan vormen in de toekomst, laten beide scenario's een overwegende toename van natte, warme en droge weersextremen zien, de klimaatfactoren welke door lage temperaturen worden bepaald laten een afname. Bij adaptatiemaatregelen is het dus belangrijk om te kijken naar maatregelen die voor meerdere situaties effectief kunnen zijn (zoals goede bodemstructuur en peilgestuurde drainage). Veel van deze maatregelen zullen soms al zijn uitgevoerd op het boerenbedrijf. Daarom kan het ook van belang zijn om te kijken naar rassenkeus. 


\section{$3 \quad$ Conclusie}

Afrondend worden hier de conclusie van de resultaten gepresenteerd en worden aanbevelingen voor verdere uitwerking en detaillering gegeven.

\subsection{Resultaten}

In alle uitwerkingen van de drie casus bedrijven treedt een toename op van het risico op als gevolg van een toename van de frequentie van de klimaatfactoren door klimaatverandering. Dat is ongeacht het scenario of de gebruikte impact. Voor de verschillende regio's en bedrijven zijn het veelal dezelfde klimaatfactoren die voor een verslechtering of verbetering van teeltomstandigheden zorgen. Zo zorgen hittegolven en warme en natte periodes in de zomer voor aanzienlijke toenames in risico's in aardappelen en zaaiuien, en verbetert de situatie voor wintertarwe en suikerbieten door afname van lange natte periodes en nachtvorst.

Voor de Noordoostpolder ligt het berekende toekomstige risico's van het bedrijf tussen de $10 \%$ voor lage impact en $\mathrm{G}\left\llcorner 2050\right.$ en 60\% (hoge impact, $W_{H} 2050$ ). Pootaardappel, gevolgd door zaai-ui en peen brengen het meeste risico met zich mee voor dit bedrijf. Voornamelijk de toenemende frequentie hittegolven en warme natte periodes met schimmels en ziekten als gevolg zijn daar verantwoordelijk voor. Wintertarwe en suikerbiet tonen geen toenemend risico en soms zelfs een verbetering van de situatie ten opzichte van de referentieperiode (1981-2010), door de afname nachtvorst het vroege voorjaar en natte periodes in de zomer.

Voor de Veenkoloniën ligt het berekende risico tussen 5\% (lage impact en GŁ2050) en 25\% (hoge impact, $W_{H}$ 2050). Zetmeelaardappel en tevens zaai-ui brengen het meeste risico met zich mee. Met name hittegolven en warme natte periodes met schimmels en ziekten als gevolg zijn daar verantwoordelijk voor. Zomergerst en suikerbiet tonen geen toenemend risico en soms zelfs een verbetering van de situatie, door de afname nachtvorst het vroege voorjaar en natte periodes in de zomer.

Voor het akkerbouw bedrijf in Zeeland is berekend dat het risico door klimaatverandering ligt tussen $5 \%$ (lage impact en $\mathrm{G}_{\llcorner} 2050$ ) en 35\% (hoge impact, $\mathrm{W}_{\mathrm{H}} 2050$ ). Consumptieaardappelen en zaaiuien brengen het grootste risico met zich mee, doordat hittegolven en warme natte periodes vaker toe gaan nemen. Wintertarwe en suikerbiet ervaren geen verslechtering van de teeltsituatie doordat nachtvorst minder vaak optreedt en de lange natte periodes in de zomer afnemen.

\subsection{Aanbevelingen}

De volgende stap is om met deze uitwerkingen letterlijk de boer op te gaan en op die manier de bewustwording voor klimaatverandering te vergroten en te beseffen dat als er geen aanpassingen gemaakt worden, de risico's aanzienlijk zullen gaan worden.

De stresstestuitwerkingen zijn besproken met betrokken organisaties uit het project en hun praktijk mensen, zoals boeren bedrijfsadviseurs. Zij weten als geen ander hoe teelten reageren op bepaalde weersomstandigheden. Dat resulteerde logischerwijs tot interessante discussies over de in de stresstest gebruikte definities en impacts van klimaatfactoren. Een update van deze getallen zou de kwaliteit van de stresstest verbeteren en daarmee de uitkomsten nog realistischer en bruikbaarder maken voor de praktijk. 
Daarnaast is het van belang dat naar andere klimaatfactoren wordt gekeken, zo speelt in bepaalde regio's verzilting een belangrijke rol en kan aardappelopslag door de toename van warme winters een toenemend probleem vormen bij opvolgende gewassen. Het is daarvoor nodig dat er onderzocht en verkend wordt in hoeverre deze factoren een impact hebben. Daarna kan verzilting bijvoorbeeld als klimaatfactor ingevoegd kan worden voor bedrijven in kustgebieden. Zoals genoemd vormt verzilting in droge periode voor zaai-uien in Zeeland een probleem. Het is daarom belangrijk om deze mee te nemen in de analyse.

Tot slot, vragen veel betrokken na het zien van de klimaatrisico's naar mogelijke oplossingsrichtingen en maatregelen. In Verstand et al., (2020) is daar een kwalitatieve aanzet naar gedaan. In andere projecten, zoals de PPS klimaatadaptatie in de open teelten wordt getracht om kwantitatieve gegevens te verzamelen over de effectiviteit en haalbaarheid van maatregelen. Deze gegevens kunnen van grote waarde zijn om aan te kunnen geven hoe er met de risico's uit de stresstest omgegaan kan worden op het boerenbedrijf en daarbuiten. 


\section{Literatuur}

Klein Tank, Albert, Jules Beersma, Janette Bessembinder, Bart van den Hurk, and Geert Lenderink. 2015. Klimaatscenario's KNMI '14.

Schaap, B. F., M. Blom-Zandstra, C. M. L. Hermans, B. G. Meerburg, and J. Verhagen. 2011. "Impact Changes of Climatic Extremes on Arable Farming in the North of the Netherlands." Regional Environmental Change 11(3):731-41.

Verstand, Daan. 2020. "Klimaat-Stresstest, Wat Beteket Klimaatverandering Voor de Open Teelten?" Verstand, Daan, Ben Schaap, Herman Schoorlemmer, Pieter De Wolf, Derk van Balen, and Jan Verhagen. 2020. Klimaatadaptatie in de Open Teelten.

van der Voort, Marcel. 2018. KWIN AGV - Kwantitatieve Informatie Akkerbouw En Vollegrondsgroenteteelt. Wageningen University and Research.

Wit de, J., D. Swart, and E. Luijendijk. 2009. "Klimaat En Landbouw Noord- Nederland: ' Effecten van Extremen '." 112. 
Correspondentie adres voor dit rapport:

Postbus 430

8200 AA Lelystad

T 0320291111

www.wur.nl/plant-research

Rapport WPR-853
De missie van Wageningen University \& Research is 'To explore the potential of nature to improve the quality of life'. Binnen Wageningen University \& Research bundelen Wageningen University en gespecialiseerde onderzoeksinstituten van Stichting Wageningen Research hun krachten om bij te dragen aan de oplossing van belangrijke vragen in het domein van gezonde voeding en leefomgeving. Met ongeveer 30 vestigingen, 5.000 medewerkers en 12.000 studenten behoort Wageningen University \& Research wereldwijd tot de aansprekende kennisinstellingen binnen haar domein. De integrale benadering van de vraagstukken en de samenwerking tussen verschillende disciplines vormen het hart van de unieke Wageningen aanpak. 


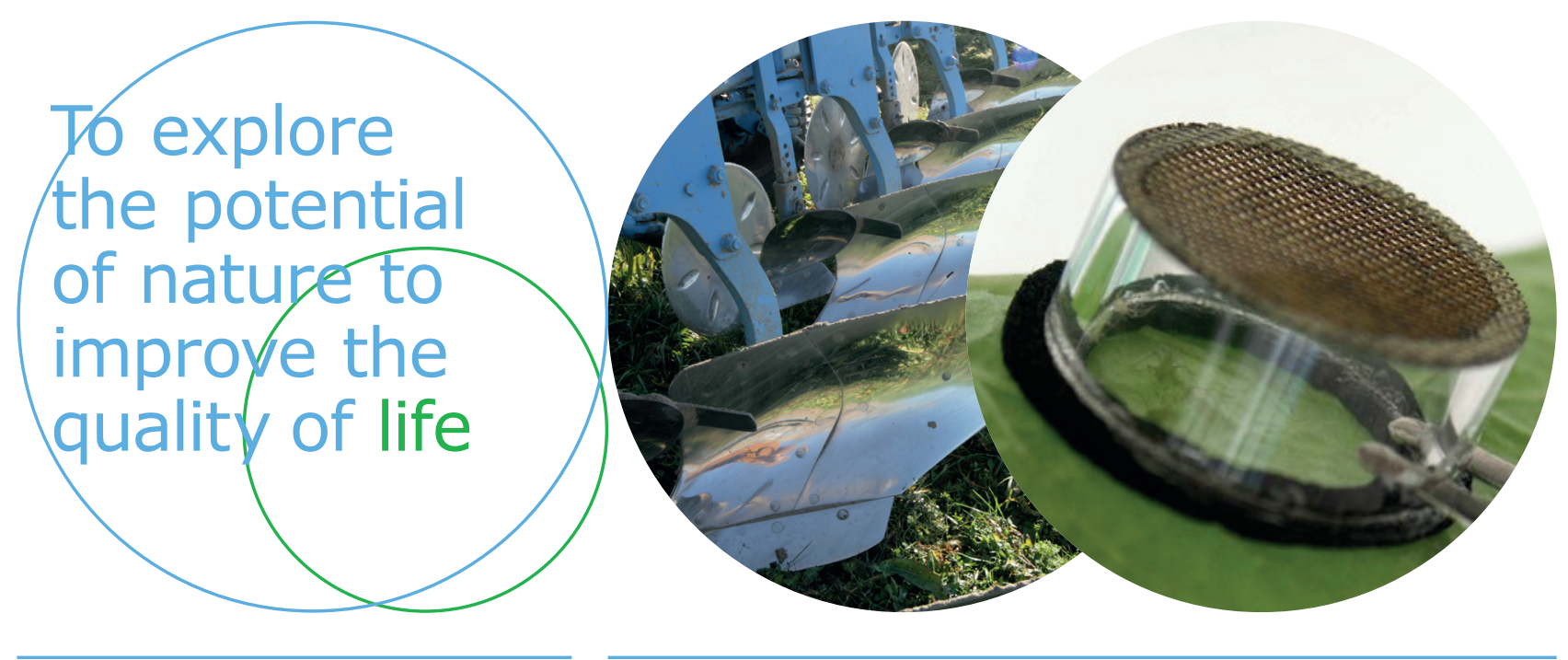

Wageningen University \& Research

Open Teelten

Edelhertweg 1

Postbus 430

8200 AK Lelystad

T (+31)3202911 11

www.wur.nl/openteelten

Rapport WPR-853
De missie van Wageningen University \& Research is 'To explore the potential of nature to improve the quality of life'. Binnen Wageningen University \& Research bundelen 9 gespecialiseerde onderzoeksinstituten van stichting DLO en Wageningen University hun krachten om bij te dragen aan de oplossing van belangrijke vragen in het domein van gezonde voeding en leefomgeving. Met ongeveer 30 vestigingen, 6.500 medewerkers en 12.500 studenten behoort Wageningen University \& Research wereldwijd tot de aansprekende kennisinstellingen binnen haar domein. De integrale benadering van de vraagstukken en de samenwerking tussen verschillende disciplines vormen het hart van de unieke Wageningen aanpak. 